\title{
Halting targeted and collateral damage to red blood cells by the complement system
}

\author{
M. Jalink ${ }^{1,2}$ - E. C. W. de Boer ${ }^{3,4}$ - D. Evers ${ }^{5}$ - M. Q. Havinga ${ }^{3}$ - J. M. I. $\operatorname{Vos}^{2,6,7}$. \\ S. Zeerleder ${ }^{3,8,9} \cdot$ M. de Haas ${ }^{1,7,10} \cdot$ I. Jongerius ${ }^{3,4}$ (D)
}

Received: 11 February 2021 / Accepted: 18 April 2021 / Published online: 30 June 2021

(C) The Author(s) 2021

\begin{abstract}
The complement system is an important defense mechanism against pathogens; however, in certain pathologies, the system also attacks human cells, such as red blood cells (RBCs). In paroxysmal nocturnal hemoglobinuria (PNH), RBCs lack certain complement regulators which sensitize them to complement-mediated lysis, while in autoimmune hemolytic anemia (AIHA), antibodies against RBCs may initiate complement-mediated hemolysis. In recent years, complement inhibition has improved treatment prospects for these patients, with eculizumab now the standard of care for PNH patients. Current complement inhibitors are however not sufficient for all patients, and they come with high costs, patient burden, and increased infection risk. This review gives an overview of the underlying pathophysiology of complement-mediated hemolysis in PNH and AIHA, the role of therapeutic complement inhibition nowadays, and the high number of complement inhibitors currently under investigation, as for almost every complement protein, an inhibitor is being developed. The focus lies with novel therapeutics that inhibit complement activity specifically in the pathway that causes pathology or those that reduce costs or patient burden through novel administration routes.
\end{abstract}

Keywords Autoimmune hemolytic anemia · Paroxysmal nocturnal hemoglobinuria $\cdot$ Complement Complement inhibitors · Complement therapeutics

M. Jalink and E. C. W. de Boer contributed equally to this work.

This article is a contribution to the Special issue on: Complement \& Disease: Out of the Shadow into the Spotlight - Guest Editors: Daniel Ricklin \& Richard B. Pouw

I. Jongerius

i.jongerius@sanquin.nl

1 Sanquin Research, Center for Clinical Transfusion Research, Plesmanlaan 125, 1066, CX Amsterdam, The Netherlands

2 Department of Hematology, Amsterdam UMC, University of Amsterdam, Amsterdam, The Netherlands

3 Sanquin Research, Department of Immunopathology, and Landsteiner Laboratory, Amsterdam University Medical Centre, Amsterdam Infection and Immunity Institute, Amsterdam, The Netherlands

4 Department of Pediatric Immunology, Rheumatology, and Infectious Diseases, Emma Children's Hospital, Amsterdam University Medical Centre, Amsterdam, The Netherlands
5 Department of Hematology, Radboud University Medical Center, Nijmegen, The Netherlands

6 Lymphoma and Myeloma Center Amsterdam (LYMMCARE), Amsterdam, The Netherlands

7 Department of Immunohematology Diagnostics, Sanquin, Amsterdam, The Netherlands

8 Department of Hematology and Central Hematology Laboratory, Inselspital, Bern University Hospital, University of Bern, Bern, Switzerland

9 Department for BioMedical Research, University of Bern, Bern, Switzerland

10 Department of Hematology, Leiden University Medical Center, Leiden, The Netherlands 


\section{Introduction}

The complement system is part of innate immunity, and abnormalities in its regulation have been associated with a wide range of pathologies [1]. Red blood cells (RBCs) seem particularly sensitive to dysregulation of the complement system, which is not surprising as RBCs are continuously exposed to complement components [2]. Either an intrinsic deficiency in complement regulation on RBCs or an extrinsic excessive complement activation against RBCs can induce premature and sometimes fulminant destruction of these cells, of which paroxysmal nocturnal hemoglobinuria (PNH) and autoimmune hemolytic anemia (AIHA), respectively, are highly characteristic. Eculizumab was the first complement inhibitor to be approved for clinical use and has revolutionized the treatment of PNH. Yet many challenges remain, including the lack of any approved complement inhibitors for the treatment of AIHA. Novel complement inhibitors to improve the treatment of PNH and address complement-mediated AIHA are currently being developed [3-5].

This review aims to give an overview of developments within the field of complement-targeting therapeutics that may in the future further optimize treatment and outcomes of complement-mediated hemolytic diseases. To this end, the working mechanism of the complement system and its contribution to the pathology of PNH and AIHA are first discussed. Second, current available complement-regulating agents and novel therapeutic developments are discussed, including potential advances in novel targets, efficacy, side effects, administration route, and patient burden.

\section{The complement system}

The complement system is an important part of innate immunity. The system is composed of plasma proteins that activate one another in a cascade. Due to its continuous presence in plasma, the system is readily available and can quickly respond to triggers, supporting the elimination of bacteria, apoptotic cells, and immune complexes. These characteristics give the system a key role in the defense against pathogens, but it also plays a role in tissue homeostasis [6-9]. In addition to its role in the innate immune system, the complement system also has a modulating role in the adaptive immune system [10].

The activation of the complement system can occur via three different pathways: the classical, lectin, and alternative pathways. These pathways each have their specific recognition molecules with corresponding triggers (reviewed in previous studies $[7,8])$. In brief, the classical pathway $(\mathrm{CP})$ is initiated by C1q, recognizing antibodies bound to target cells, activating $\mathrm{C} 1 \mathrm{r}$ which in turn activates the serine protease $\mathrm{C} 1 \mathrm{~s}$ and its downstream pathway $[8,11]$. The lectin pathway (LP) is activated via mannose-binding lectin (MBL), collectins, and ficolin which recognize microbial carbohydrate structures. Upon recognition of their specific patterns, they form a complex with MBL-activated serine proteases (MASPs) which induces further activation of the LP [12]. Both CP and LP activation result in $\mathrm{C} 4$ and $\mathrm{C} 2$ cleavages, which leads to the formation of the $\mathrm{C} 3$ convertase $(\mathrm{C} 4 \mathrm{bC} 2 \mathrm{a})$ that can cleave $\mathrm{C} 3$ into $\mathrm{C} 3 \mathrm{a}$ and $\mathrm{C} 3 \mathrm{~b}$ [8]. Lastly, the alternative pathway (AP) can be activated spontaneously by background hydrolysis of $\mathrm{C} 3$, and it acts as an amplification route of complement activation, as it is activated following $\mathrm{C} 3 \mathrm{~b}$ deposition via the other pathways. Factor $\mathrm{B}(\mathrm{FB})$ will bind to $\mathrm{C} 3 \mathrm{~b}$ and upon cleavage by factor D (FD); the $\mathrm{C} 3$ convertase $(\mathrm{C} 3 \mathrm{bBb})$ is formed. Similar to the $\mathrm{C} 3$ convertase of the $\mathrm{CP} / \mathrm{LP}$, this convertase cleaves $\mathrm{C} 3$, forming $\mathrm{C} 3 \mathrm{a}$ and $\mathrm{C} 3 \mathrm{~b}[8,13]$. Both $\mathrm{C} 4 \mathrm{~b}$ and $\mathrm{C} 3 \mathrm{~b}$, formed upon complement activation, opsonize target cells, which induces phagocytosis. Furthermore, $\mathrm{C} 3 \mathrm{~b}$ also contributes to the formation of $\mathrm{C} 5$ convertases, which cleaves $\mathrm{C} 5$ into $\mathrm{C} 5 \mathrm{a}$ and $\mathrm{C} 5 \mathrm{~b}$. $\mathrm{C} 5 \mathrm{~b}$ interacts with $\mathrm{C} 6$, resulting in subsequent binding of $\mathrm{C} 7, \mathrm{C} 8$, and multiple $\mathrm{C} 9$ molecules. These molecules together form the membrane attack complex (MAC) that creates a pore by inserting into the membrane of the target cell, resulting in cell lysis [8]. In the context of RBCs, opsonization and subsequent phagocytosis is a process of extravascular hemolysis (Fig. 1A), while MAC activation and subsequent cell lysis refer to intravascular hemolysis (Fig. 1B) [2]. Cleavage of $\mathrm{C} 3$ and $\mathrm{C} 5$ also results in the release of the anaphylatoxins $\mathrm{C} 3 \mathrm{a}$ and $\mathrm{C} 5 \mathrm{a}$, which are chemoattractants and modulators of inflammation. For example, they recruit macrophages and neutrophils and induce pro-inflammatory cytokine production by $T$ cells and antigen-presenting cells $[9,14]$.

As the complement system can be very harmful and is continuously ready to be activated by invading foreign organisms, it is important to prevent unwanted complement attacks of host cells. In order to protect host cells, an intricate system of complement regulators is in place to keep the complement system under control. Regulators can effectively modulate all steps in the complement activation cascade and can be divided into two groups: the membrane-bound and the soluble complement regulators in plasma [6]. The membrane-bound complement regulators consist of complement receptor 1 (CR1 or CD35), membrane co-factor protein (MCP or CD46), decayaccelerating factor (DAF or CD55), complement receptor of the immunoglobulin family (CRIg), and CD59 (Table 1). CR1 binds $\mathrm{C} 3 \mathrm{~b}$ and $\mathrm{C} 4 \mathrm{~b}$ and can induce the decay of both $\mathrm{C} 3$ and C5 convertases but also functions as a co-factor for factor I (FI) $[21,22]$. CD46 can also bind $\mathrm{C} 3 \mathrm{~b}$ and $\mathrm{C} 4 \mathrm{~b}$ but does not have any decay-accelerating activity in itself, realizing its regulatory activity solely as an FI co-factor [23, 24]. CD55 and CD59 are both glycosylphosphatidylinositol (GPI)-anchored membrane-bound complement regulators. CD55 accelerates the decay of the $\mathrm{C} 3$ convertases of all pathways, while CD59 acts on the terminal pathway by preventing MAC 


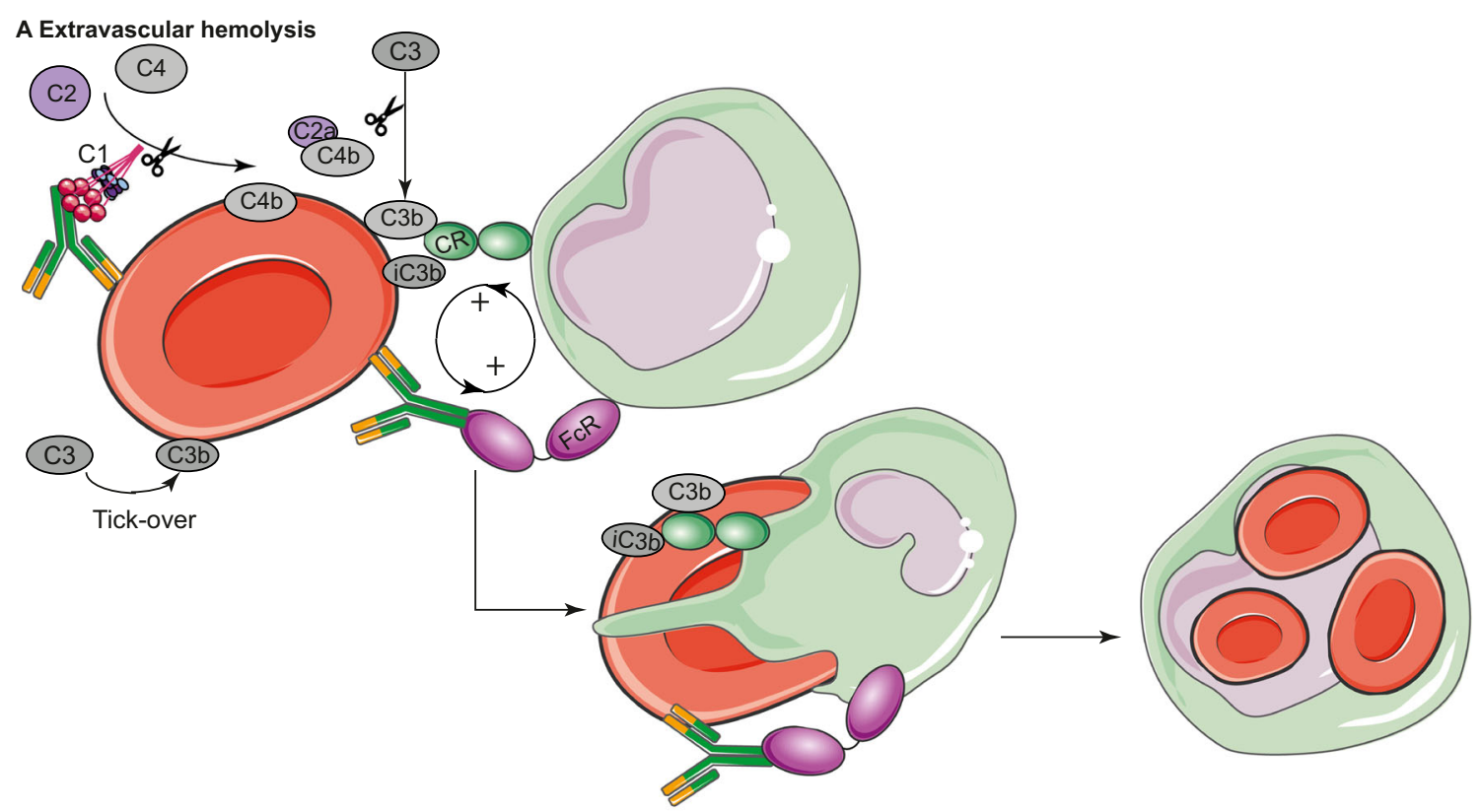

B Intravascular hemolysis

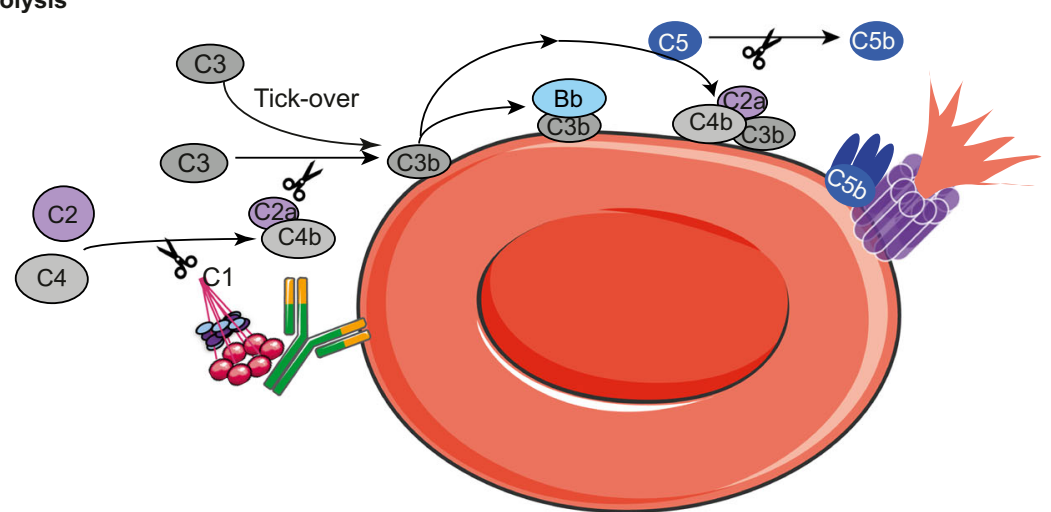

Fig. 1 Mechanisms of extravascular and intravascular hemolysis. (A) Complement activation on RBCs can occur via the CP (in AIHA) or via the $\mathrm{AP}$ (in $\mathrm{PNH}$ ). Extravascular hemolysis via the $\mathrm{CP}$ is the consequence of opsonization of the RBC with antibodies, fragments of $\mathrm{C} 4(\mathrm{C} 4 \mathrm{~b}$ or $\mathrm{C} 4 \mathrm{~d})$, and/or fragments of $\mathrm{C} 3(\mathrm{C} 3 \mathrm{~b}, \mathrm{iC} 3 \mathrm{~b}$, or $\mathrm{C} 3 \mathrm{~d})$. Extravascular hemolysis via the AP (tick-over) depends on opsonization with $\mathrm{C} 3$ fragments only. Phagocytes express $\mathrm{Fc}$ and complement receptors, which bind to antibodies or the complement components on the target cell, respectively. The synergy between both receptors results in highly effective phagocytosis. Upon phagocytosis, the whole $\mathrm{RBC}$ is internalized into the phagocyte within the phagosome. (B) Intravascular hemolysis can be initiated by both the AP and CP. C1q can bind to antibodies on an RBC, which induces the cleavage of $\mathrm{C} 2$ and $\mathrm{C} 4$, forming the $\mathrm{CP}$ convertase $\mathrm{C} 4 \mathrm{~b} 2 \mathrm{a}$. Both the $\mathrm{CP}$ convertase and spontaneous background hydrolysis (tick-over) of $\mathrm{C} 3$ in the AP result in $\mathrm{C} 3 \mathrm{~b}$ cleavage. $\mathrm{C} 3 \mathrm{~b}$ can then deposit on the cell, or bind to $\mathrm{C} 4 \mathrm{bC} 2 \mathrm{a}$, forming the $\mathrm{C} 5$ convertase. Upon cleavage of $\mathrm{C} 5, \mathrm{C} 5 \mathrm{~b}$ is formed, which associates with $\mathrm{C} 6, \mathrm{C} 7, \mathrm{C} 8$, and multiple $\mathrm{C} 9$ molecules to form the membrane attack complex (MAC), which inserts itself into the cell membrane, resulting in lysis. Figure created using Servier Medical Art formation [6, 25]. Lastly, CRIg binds to $\mathrm{C} 3 \mathrm{~b}$ and $\mathrm{iC} 3 \mathrm{~b}$ and inhibits the AP C3 convertase $[18,26]$. The expression profile of these membrane-bound regulators differs per cell type. For example, RBCs, the main subject of this review, have CR1, CD55, and CD59 on their surface but lack CD46 and CRIg [24].

The group of soluble complement regulators consists of $\mathrm{C} 1$ inhibitor (C1-INH), $\mathrm{C} 4$ binding protein (C4BP), factor $\mathrm{H}$ $(\mathrm{FH})$, clusterin $(\mathrm{CLU})$, vitronectin $(\mathrm{Vn})$, and FI which are constitutively present in plasma. $\mathrm{C} 1-\mathrm{INH}$ and $\mathrm{C} 4 \mathrm{BP}$ regulate both the LP and CP $[27,28]$. FH on the other hand is a strong regulator of the AP, with recognition sites for host cells and $\mathrm{C} 3 \mathrm{~b}$ in order to prevent or reverse the formation of the AP convertase on host cells $[29,30]$. Both CLU and Vn inhibit MAC formation [6, 28]. Lastly, FI inactivates $\mathrm{C} 3 \mathrm{~b}$ and $\mathrm{C} 4 \mathrm{~b}$ and thus regulates all complement pathways. For this, FI needs the aid of a co-factor, a role that is played by other complement regulators: C4BP, FH, CR1, or CD46 [31]. The inactivation of $\mathrm{C} 3 \mathrm{~b}$ by $\mathrm{FI}$ is mediated by the subsequent cleavage of $\mathrm{C} 3 b$ to $\mathrm{iC} 3 \mathrm{~b}$ and of $\mathrm{iC} 3 \mathrm{~b}$ to $\mathrm{C} 3 \mathrm{c}$ and $\mathrm{C} 3 \mathrm{dg}$. For the latter, only CR1 can act as a co-factor, and this step is key to prevent iC3b-mediated activation of neutrophils through CR3 
Table 1 Complement receptors and their respective ligands

\begin{tabular}{|c|c|c|c|c|}
\hline Receptor & Ligands & Expressed on & Effect & Ref. \\
\hline $\mathrm{CR} 1$ or $\mathrm{CD} 35$ & $\mathrm{C} 3 \mathrm{~b}, \mathrm{C} 4 \mathrm{~b}$ & $\begin{array}{l}\text { RBCs, monocytes, macrophages, } \\
\text { renal podocytes }\end{array}$ & $\begin{array}{l}\text { Complement regulation by decay of } \mathrm{C} 3 \\
\text { and } \mathrm{C} 5 \text { convertases, induction of phagocytosis }\end{array}$ & {$[8,10,15]$} \\
\hline $\mathrm{CR} 2$ or $\mathrm{CD} 21$ & iC3b, C3d, C3dg & $\mathrm{B}$ cells & Co-stimulatory in B cell activation & {$[8,10,15,16]$} \\
\hline $\mathrm{CR} 3$ or $\mathrm{CD} 11 \mathrm{~b} / \mathrm{CD} 18$ & $\mathrm{C} 3 \mathrm{~b}, \mathrm{iC} 3 \mathrm{~b}, \mathrm{C} 3 \mathrm{~d}$ & Leucocytes & Induction of phagocytosis & {$[8,10,15,17]$} \\
\hline $\mathrm{CR} 4$ or $\mathrm{CD} 11 \mathrm{c} / \mathrm{CD} 18$ & $\mathrm{C} 3 \mathrm{~b}, \mathrm{iC} 3 \mathrm{~b}, \mathrm{C} 3 \mathrm{c}$ & Leucocytes & Induction of phagocytosis & {$[8,10,15,17]$} \\
\hline CRIg & $\mathrm{C} 3, \mathrm{iC} 3 \mathrm{~b}, \mathrm{C} 3 \mathrm{c}$ & Dendritic cells, Kupffer cells & Induction of phagocytosis, $\mathrm{C} 3$ convertase inhibition & {$[10,15,18-20]$} \\
\hline
\end{tabular}

binding, which is described subsequently in more detail [32]. The sensitivity of RBCs to complement-mediated attack depends on the protection offered by both membrane-bound and soluble complement regulators [25].

As described previously, complement activation leads to opsonization of target cells with $\mathrm{C} 3 \mathrm{~b}$ and $\mathrm{C} 4 \mathrm{~b}$, which is of major importance for phagocytosis. CRs are membranebound molecules expressed on various immune cells and play a key role in this phagocytic process (see Table 1). Recognition of $\mathrm{C} 3 \mathrm{~b}$ and $\mathrm{C} 4 \mathrm{~b}$ by CRs will lead to activation of immune cells, resulting in induction of phagocytosis. Currently, five complement receptors have been identified: CR1, CR2, CR3, CR4, and CRIg [8]. Next to its role in complement regulation, $\mathrm{CR} 1$ is expressed on RBCs, monocytes, macrophages, neutrophils, and renal podocytes and can bind both $\mathrm{C} 3 \mathrm{~b}$ and $\mathrm{C} 4 \mathrm{~b}$. CR2 is structurally similar to CR1, although it is only expressed on B cells and thus mainly serves as a co-stimulatory molecule for activation of the B cell upon the interaction between antigen and B cell receptor, in which case CR2 amplifies signal transduction [8, 15, 16, 33]. This could play a role in AIHA, where $\mathrm{C} 3 \mathrm{~d}$ is detected on the $\mathrm{RBC}$ surface, as this could thus induce increased B cell receptor signaling and subsequent antibody production [34]. CR3 and CR4 both belong to the integrin family but recognize different C3 fragments (see Table 1). They are expressed on leukocytes, especially on macrophages, monocytes, and NK cells, but also on some B and T cells [17]. Lastly, CRIg is the most recently discovered complement receptor, which belongs to the immunoglobin superfamily. CRIg is expressed only on dendritic cells and Kupffer cells, which are subtypes of macrophages specifically present in the liver [19]. Kupffer cells play an important role in the clearance of pathogens from the bloodstream by phagocytosis, and their contribution to intravascular hemolysis has not been elucidated yet. For the binding of C3 fragments and clearance of C3-opsonized pathogens by Kupffer cells, CRIg has been deemed essential based on studies in knockout mice [26].

Apart from complement-mediated phagocytosis, IgG-Fc receptors $(\mathrm{FcR})$ on phagocytes can initiate antibodymediated phagocytosis, which is of major importance in AIHA, as described subsequently. These receptors bind to the Fc region of antibodies that have opsonized cells or other particles. FcRs come in different types, which differ in the antibody (sub)classes they recognize and their affinity for the antibodies. Next, they can carry out specific immune effector functions [35-37]. Antibody characteristics, such as antibody class and Fc-glycosylation profile, are important for both interactions between antibody and FcR and complement activation [35, 36, 38]. Splenic red pulp macrophages, involved in clearing IgG-opsonized RBCs, distinctively express all types of activating Fc $\gamma$ Rs and are specifically important in the pathophysiology of AIHA [39]. Altogether, the interplay between complement and antibody opsonization of target cells and subsequent activation of CRs and FcRs determines the process of phagocytosis and is of synergistic nature, which, in the context of RBCs, results in extravascular hemolysis (Fig. 1A). C3 fragment opsonization seems mainly responsible for particle binding by phagocytes, while IgG opsonization seems important for particle ingestion [40]. The presence of C3 fragments together with IgG on a particle can significantly reduce the amount of $\mathrm{IgG}$ required to induce ingestion and even seems essential for effective induction of phagocytosis [41].

\section{Complement-mediated diseases affecting RBCs}

Several pathologies have been described where overactivation and dysregulation of the complement system induce RBC damage. This is not surprising, as RBCs are continuously exposed to the complement system in the bloodstream [2]. Of these pathologies, PNH, AIHA, and aHUS are best defined but in more rare cases involving deficiencies of a single complement regulator (CD55 or CD59) causing similar symptoms have been described [42]. In this review, we will focus on the underlying mechanisms and clinical management of AIHA and $\mathrm{PNH}$, as the damage to RBCs in these pathologies is fully complement mediated. The pathology of aHUS has been extensively reviewed [43], and the common belief is that hemolysis in aHUS is not solely complement mediated but merely a result of mechanistic hemolysis, which falls outside 
the scope of this current review [43]. However, very recent data obtained in an in vitro model of aHUS showed that hemolysis can be a direct result of AP activity as well [44]. More research will be needed to determine the role of the complement system on RBC destruction in aHUS in vivo.

\section{Complement in PNH}

PNH is a rare hemolytic disease with an estimated incidence of 1-1.5 cases per million individuals worldwide [45]. Clinical disease is caused by clonal expansion of hematopoietic stem cells with an acquired somatic mutation in the phosphatidylinositol glycan-A (PIGA) gene. The absence of PIGA enzyme activity results in hematopoietic cell deficiency in GPI-anchored proteins, including the complement regulators CD55 and CD59. As CD55 is highly important in regulating the AP and $\mathrm{C} 3$ convertases, while CD59 prevents the formation of the MAC, affected cells are rendered highly vulnerable to the effects of activation of $\mathrm{C} 3, \mathrm{C} 5$, and the terminal pathway of complement, culminating in the formation of the MAC (Fig. 2A) [46]. Protection of PNH RBCs against AP activity by the soluble complement regulator FH is very important and does allow the RBCs to endure in circulation for days instead of immediate cell lysis, which might be expected in cells deficient in GPI-anchored proteins [47].

Hemolytic anemia, mainly due to intravascular hemolysis, is the hallmark of PNH, resulting in the release and accumulation of free hemoglobin and iron in plasma, subsequent nitric oxide (NO) depletion, and upregulation of proinflammatory cytokines. Thrombosis, at any site and both venous and arterial, has been the major direct cause of death in PNH prior to the availability of terminal complement inhibitors. Various mechanisms play a part here, all characterized by excessive complement activation against hematopoietic cells, including the formation of prothrombotic platelet microvesicles, platelet activation, and platelet aggregation via NO scavenging. There is defective fibrinolysis related to a lack of several GPI-linked coagulation regulators and a general pro-inflammatory state. Several of its other symptoms, such as dysphagia and erectile dysfunction, are related to general smooth muscle dystonia as a consequence of the overall NO scavenging $[3,45,48]$.

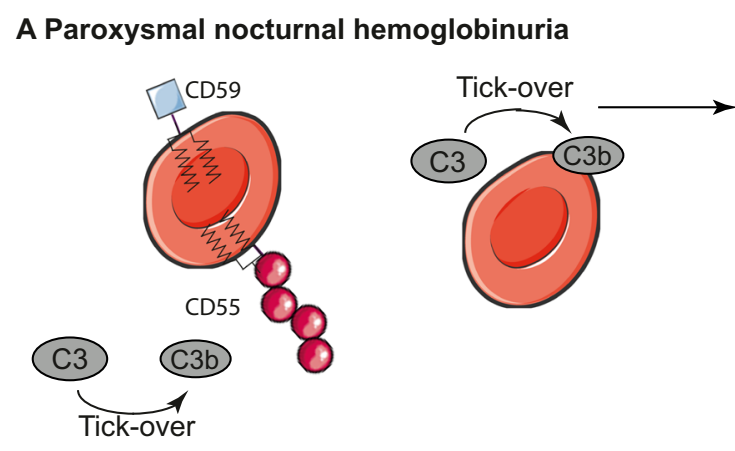

\section{B Auto-immune hemolytic anemia}
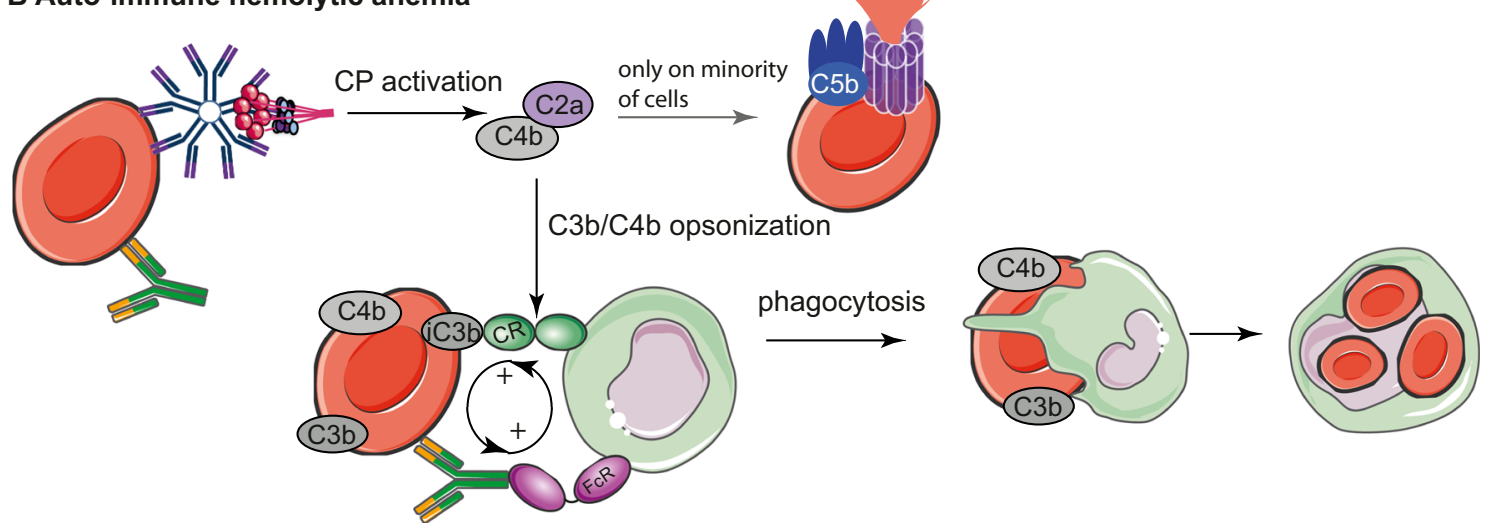

Fig 2. Mechanism behind complement-mediated destruction of RBCs in PNH and AIHA. (A) Healthy RBCs express the GPI-anchored complement regulator $\mathrm{CD} 55$, which induces decay of $\mathrm{C} 3$ convertases, and CD59, which prevents MAC formation. PNH RBCs, however, do not express these regulators, meaning that $\mathrm{C} 3 \mathrm{~b}$ arising from tick-over can result in opsonization of the RBC. On PNH RBCs, further complement activation is not prevented and can result in MAC formation and intravascular hemolysis or in extravascular hemolysis by phagocytosis

of C3 fragment-opsonized RBCs in the liver or spleen, which are often $\mathrm{iC} 3 \mathrm{~b}$ or $\mathrm{C} 3 \mathrm{~b}$ opsonized in PNH patients. (B) RBC autoantibodies in AIHA patients of either IgG or IgM class bind to RBCs and can induce $\mathrm{CP}$ activation, which leads to further opsonization of the RBC with complement and in some cases to MAC formation and direct lysis. The opsonized RBC can be phagocytosed via the IgG-Fc receptors and complement receptors. Figure created using Servier Medical Art 


\section{Current management of PNH}

The treatment of PNH has drastically improved since the introduction of terminal complement inhibitors [49]. Eculizumab is a recombinant humanized monoclonal antibody that selectively targets $\mathrm{C} 5$, preventing its cleavage into C5a and C5b and subsequently the formation of the MAC [49, 50]. As such, it compensates for the CD59 deficiency in PNH but does not overcome the CD55 deficiency. Indeed, two large phase 3 clinical studies (TRIUMPH study [NCT00122330] and SHEPHERD study [NCT00130000]) allow for a significant reduction of intravascular hemolysis, transfusion requirements, and thrombosis incidences following initiation of eculizumab treatment $[51,52]$. In almost all patients, a mild to severe residual anemia persists, with about $30 \%$ of patients remaining transfusion dependent $[46,53]$. Next to underlying $\mathrm{PNH}$-related bone marrow failure, transfusion dependency is explained by extravascular hemolysis due to ongoing $\mathrm{C} 3 \mathrm{~b}$ deposition on RBCs [51, 52].

Further developments of eculizumab analogs with modifications of its $\mathrm{Fc}$ regions resulted in enhanced recycling [54]. This new C5-specific monoclonal antibody, ravulizumab, only very recently proved equally efficient as compared to eculizumab, benefits from an approximately fourfold increased half-life, and thereby a dosing interval of 8 rather than 2 weeks as compared to eculizumab [55].

Although eculizumab is effective in most patients, failure to respond to eculizumab has been described. This is mostly observed among Asian PNH patients bearing a C5 polymorphism, with a prevalence of approximately $3.2 \%$ among Japanese and $1 \%$ among Chinese Han patients with PNH [56]. This genetic variant of $\mathrm{C} 5$ prevents binding of eculizumab and thus abrogates adequate complement inhibition. Another C5 variant interfering with the binding of eculizumab was recently described in a Caucasian male patient. Upon treatment switch to coversin, a small recombinant C5-inhibiting lipocalin protein with the additional advantage of subcutaneous administration, hemolysis was halted and clinical symptoms improved significantly [57]. The AK585 study (ClinicalTrials.gov, NCT03427060) will further investigate if coversin may be a useful therapy for other $\mathrm{PNH}$ patients who are resistant to eculizumab therapy due to genetic variants of C5. Furthermore, C5 inhibition does not prevent the continuous extravascular clearance of $\mathrm{C} 3$ fragment-opsonized RBCs by macrophages in the reticuloendothelial system, as first described by Risitano et al. [58]. This phenomenon results in low-level hemolysis persisting in the majority of PNH patients treated with eculizumab [59]. Susceptibility to this phenomenon has been linked to CR1, which can play a protective role against $\mathrm{C} 3 \mathrm{~b}$ opsonization. $\mathrm{CR} 1$ has two co-dominant alleles, which lead to high $(\mathrm{H})$ or low (L) expression of CR1 on the RBC surface. This decreased expression on the RBC surfaces leads to reduced
C3b decay, which increases opsonization levels that induce extravascular hemolysis. Thus, patients with an $\mathrm{H} / \mathrm{L}$ or $\mathrm{L} / \mathrm{L}$ genotype have been shown to require more transfusions upon eculizumab treatment than patients with the $\mathrm{H} / \mathrm{H}$ genotype [60]. This ongoing extravascular hemolysis may be overcome by more upstream complement inhibition, at the $\mathrm{C} 3$ level, as discussed in more detail subsequently [61].

\section{Complement in AIHA}

AIHA is a heterogeneous disease caused by autoantibodyinitiated destruction of RBCs, in which complement activation may play a role. It is a rare disease with an incidence of $10-30$ cases per million individuals in adults and with an even lower incidence in children [62]. AIHA can be classified as primary (idiopathic) or secondary. The latter relates to underlying diseases or conditions which trigger the humoral immune response, including lymphoproliferative malignancies, autoimmune diseases, infections, immunodeficiencies, and certain drugs [63, 64]. The diagnosis of AIHA is based on the presence of hemolytic anemia and the serological detection of anti-RBC autoantibodies or complement on the RBCs by the direct antiglobulin test (DAT). Autoantibodies in AIHA can be of IgG, IgA, and IgM isotypes. According to the thermal amplitude, defined as the highest temperature at which the autoantibody can bind its antigen, and the isotype, AIHA can be divided into warm ( $60-70 \%$ of cases) and cold (20-25\% of cases) AIHA [65]. Cold AIHA (cAIHA) is further classified as primary cold agglutinin disease (CAD), typically associated with a low-grade lymphoproliferative disorder producing a (often low level) monoclonal IgM, while cold agglutinin syndrome (CAS) is secondary to an underlying disease $[65,66]$. Less often, mixed or atypical forms of AIHA and paroxysmal cold hemoglobinuria (PCH) are diagnosed [63]. The degree of complement deposition on the RBC depends on the isotype and even IgG subclass, thermal amplitude, the recognized targets, and the number of bound autoantibodies. Autoantibodies from IgM isotype (and to a lesser extent, the $\operatorname{IgG}$ isotype subclasses 1 and 3 ) are strong complement activators and able to bind $\mathrm{Clq}$ upon $\mathrm{RBC}$ targeting. Thus, these are responsible for the activation of the CP of the complement system [67]. IgM autoantibodies are typically cold agglutinins associated with cAIHA, while warm IgM autoantibodies are rare.

Warm AIHA (wAIHA) is characterized by polyclonal autoantibodies with an optimal binding temperature at $37^{\circ} \mathrm{C}$. The DAT is typically positive for autoantibodies of IgG and/ or to a lesser extent of IgA class (15-20\%). The density of warm autoantibodies of IgG or IgA type on the RBC membrane is usually not sufficient to serve as a binding place of $\mathrm{C} 1 \mathrm{q}$, and hemolysis in wAIHA is typically considered to be complement independent. Despite that, complement deposition, mainly $\mathrm{C} 3 \mathrm{~d}$, may be detected in the DAT. We previously 
showed that in these cases, IgM isotype autoantibodies are often present and found indications that these are responsible for $\mathrm{C} 3$ deposition $[62,68]$. In wAIHA, the opsonized RBCs are mostly cleared by $\mathrm{FcR}$, but $\mathrm{C} 3$ deposition may add to the level of extravascular hemolysis in the spleen and liver (Fig. 2B) [66]. Intravascular hemolysis is not often seen in wAIHA.

In patients with cAIHA, the DAT is positive for complement, and IgM binding may also be detected. However, as IgM often has low affinity at body temperature, it may bind at the extremities or body parts with low temperature and detach from the RBC membrane at $37^{\circ} \mathrm{C}$. Therefore, the detection of $\mathrm{C} 3$ fragments in the DAT may be the only remnant of the initial complement activity caused by an IgM autoantibody [68]. The involved IgM autoantibodies optimally bind to the $\mathrm{RBC}$ antigens at $3-4^{\circ} \mathrm{C}$. They are likely only pathogenic if the thermal amplitude exceeds $30^{\circ} \mathrm{C}$. Clinically, cAIHA is not only characterized by hemolytic anemia but also by RBC agglutination in the peripheral circulation, leading to acrocyanosis [69]. Although in patients with all types of AIHA, membrane-bound complement regulators are normally expressed; in severe cases, complement activation can result in the formation of the MAC, leading to intravascular hemolysis [61, 69-72].

While the majority of AIHA is either wAIHA or cAIHA, there are some rare variants. Mixed AIHA (10\% of cases) is defined as the combination of a warm type of IgG autoantibodies and evidence of a cold type of autoantibody. The DAT is positive for $\mathrm{IgG}$ and $\mathrm{C} 3 \mathrm{~d}$ [65]. PCH is a very rare AIHA subtype. It occurs almost exclusively in young children in reaction to a viral infection and, although it can be severe, is a self-limiting disease. In adults, it is exceedingly rare and can be associated with infections (tertiary syphilis). $\mathrm{PCH}$ is caused by a strongly complement-activating polyclonal IgG autoantibody predominantly directed against the $\mathrm{P}$ antigen on the $\mathrm{RBC}$. The IgG autoantibody binds only at low temperatures but is able to initiate complement activation to such an extent that it leads to the formation of the MAC and subsequently intravascular hemolysis [66]. The DAT is usually negative for $\operatorname{IgG}$ and frequently only positive for C3 fragments [73]. Finally, (rare) atypical forms of AIHA caused by warm IgM autoantibodies and AIHAs with a negative DAT exist $[63,65]$.

\section{Current management of AIHA}

The AIHA subtype directs the choice of therapy. In secondary AIHA, treatment of the underlying disease is an important part of the therapy. Primary wAIHA is traditionally treated with corticosteroids, which leads to a response in approximately $80 \%$ of patients $[63,64]$. However, many of these responses are temporary. Rituximab, an anti-CD20 antibody, is often considered as a second line of treatment with an overall response rate of around $80 \%[64,65]$, although relapses are frequently observed [65]. In refractory or relapsed patients, splenectomy and alternative immunosuppressive drugs (such as azathioprine, mycofenolate mofetil, cyclosporin, and endoxan) can be considered $[4,64,65]$. The use of complement inhibitors has not been extensively studied in wAIHA thus far [74]. However, as complement activation may be part of the pathophysiology of WAIHA, complement inhibition with pegcetacoplan ( $\mathrm{C} 3$ inhibitor) is investigated in an ongoing clinical trial. Also, a clinical trial with the $\mathrm{C} 1 \mathrm{q}$ inhibitor ANX005 is planned including wAIHA patients with evidence of complement involvement (ClinicalTrials.gov, NCT03226678 and NCT04691570).

In primary cAIHA or CAD, the anemia is often mild to moderate, and many patients can be managed conservatively with the advice to avoid cold exposure. Some patients, however, suffer from significant hemolytic anemia or acrocyanosis despite thermal protection. In these cases, rituximab is the first line of treatment; however, the overall response rate is only $50 \%$, and the median duration of response is less than 12 months $[65,66]$. Cytotoxic combinations such as rituximab with bendamustine or fludarabine induce higher response rates (70-75\%) and more sustained remissions (several years). However, these therapies are associated with short-term (infections, cytopenia) and long-term (secondary malignancies, stem cell toxicity) adverse events. In addition, time to response can be weeks to months, and over $25 \%$ of patients with CAD do not respond to chemotherapy $[75,76]$.

Recently, complement inhibition has become the focus of clinical studies in cAIHA. The first study of complement inhibition in $\mathrm{CAD}$ was a phase 2 prospective clinical trial with the C5 inhibitor eculizumab (DECADE) [77]. In twelve patients with chronic CAD, and one with acute CAS, eculizumab significantly reduced intravascular hemolysis and transfusion requirements. However, it did not normalize $\mathrm{Hb}$ levels and did not improve quality of life [77]. The lack of effect of this terminal complement inhibitor is probably related to ongoing extravascular hemolysis via phagocytosis in the liver. To date, the use of eculizumab has been discussed for the treatment of rare cases of severe intravascular hemolysis in exacerbations or refractory cAIHA [78].

Considering most of the hemolysis in cAIHA takes place via phagocytosis of $\mathrm{C} 3 \mathrm{~b}$-opsonized $\mathrm{RBCs}$ in the liver, inhibition at a more proximal level of the complement cascade may be a more effective approach. Sutimlimab, a humanized C1s monoclonal antibody, was studied in phase 3 clinical trial for transfusion-dependent cAIHA patients (CARDINAL study, ClinicalTrials.gov, NCT03347396). It induced a rapid and sustained effect in patients with CAD with a resolution of hemolysis and a resolution of transfusion independency in $70 \%$ of the patients, together with an improvement in quality of life. These clinical improvements correlated with the normalization of complement factor $\mathrm{C} 4$ levels and decreased CP activity [79]. Results are awaited for the CADENZA 
study, where sutimilimab is investigated in the (more prevalent) transfusion-independent CAD population (ClinicalTrials.gov, NCT03347422). BIVV020, a monoclonal antibody targeting activated $\mathrm{C} 1 \mathrm{~s}$, is currently studied in a phase $1 \mathrm{~b}$ clinical trial. An ongoing phase 2 trial investigates the $\mathrm{C} 3 \mathrm{a} / \mathrm{b}$ inhibitor pegcetacoplan in CAD (ClinicalTrials.gov, NCT03226678). In line with upstream complement inhibition at the $\mathrm{C} 1$ level, the use of plasmaderived $\mathrm{C} 1-\mathrm{INH}$, since long approved and available for the treatment of hereditary angioedema, has been reported in a single patient with cAIHA. Here, C1-INH was effective and safe in controlling complement-mediated AIHA [80, 81]. Currently, we are performing a phase 2 open-label study that examines the effect of co-administration of C1-INH and blood transfusion in severe cAIHA on the recovery of allogeneic RBCs (ClinicalTrialsRegister.eu: 2012-003710-13).

$\mathrm{PCH}$ is often transient, and treatment for $\mathrm{PCH}$ is mainly supportive of maintaining warm temperatures and blood transfusions if required $[66,73,82]$. As the hemolytic anemia in $\mathrm{PCH}$ is fully complement mediated, there is a rationale for the use of complement inhibitors in severe cases of $\mathrm{PCH}$. There are some case reports describing the effect of eculizumab on intravascular hemolysis in patients with $\mathrm{PCH}$ with varying results $[83,84]$.

While there are currently no approved complementdirected therapies for cAIHA, complement inhibitors are expected to change the therapeutic landscape for this disease. But despite these promising results, it is important to realize that complement inhibition does not halt autoantibody production, and its binding to RBC epitopes as the underlying antibody-producing clone is not targeted. This is especially relevant in IgM-mediated AIHA with both symptomatic hemolysis and agglutination disease, as complement inhibition only targets the first but not the latter. Thus, complement inhibition at any level in the complement cascade does not benefit the patient suffering from acrocyanosis [77]. In these cases, a clone-directed approach, that is, with immunochemotherapy or possibly novel B cell-directed therapies such as BTK inhibition, may be more suited.

\section{Complement inhibition nowadays and in the future}

\section{Disadvantages of the use of complement inhibitors}

The development of terminal complement inhibitors has revolutionized the treatment of $\mathrm{PNH}$, and the arrival of more proximal complement inhibitors potentially will have a dramatic impact on the treatment of complement-mediated AIHA. However, these treatments come with several limitations. First, as complement inhibition does neither cures nor affects the underlying disease, continuous treatment is needed to maintain response. In the case of eculizumab, this involves lifelong intravenous infusions at a bimonthly frequency, coming with immense expenses, limited patient compliance, and impairment of patients' quality of life [45]. Especially in $\mathrm{PNH}$, it is essential to strictly adhere to dosing schemes as any delay in infusion risks loss of $\mathrm{C} 5$ inhibition with subsequent massive hemolysis and secondary life-threatening (thrombotic) events. The increased half-life of ravulizumab in this respect overcomes some of these logistic aspects. Similarly, in cAIHA, the second-generation C1s inhibitor BIVV020 is expected to have a prolonged half-life compared to sutimlimab due to selectively inhibiting the activated form of $\mathrm{C} 1 \mathrm{~s}$ rather than total C1s. Currently, this agent is being evaluated in an extended phase 1b study (ClinicalTrials.gov, NCT04269551).

Second, complement is an important part of the host defense mechanism, especially against virulent encapsulated bacteria. Chronic inhibition warrants proper antimicrobial protection by a comprehensive vaccination schedule, while some also advise long-term antibiotics [85]. So far, realworld data concerning the use of eculizumab demonstrated an annual incidence of meningococcal disease of $0.5 \%$ per year. Importantly, $95 \%$ of meningococcal infections originated in patients not vaccinated against all serotypes. However, even with complete serotype vaccination, ex vivo data have shown increased baseline risks due to an eculizumab-induced inhibition of the pro-inflammatory peptide $\mathrm{C} 5 \mathrm{a}$, which is essential for upregulation of microbial phagocytosis [76]. Theoretically, the risk of such infections in patients treated with a more upstream inhibitor specific for $\mathrm{C} 3$, thereby both blocking bacterial opsonization and bacterial killing via MAC, may be even higher. Substantial clinical data are currently lacking, although small ongoing trials so far supported a favorable safety profile $[86,87]$.

Third, complement inhibition upstream of C5 may optimize achievement of treatment goals in the patients with ongoing hemolysis due to $\mathrm{C} 3$ deposition or for patients with $\mathrm{C} 5$ variation, rendering C5-targeted therapy ineffective [56, 57]. Finally, but only theoretically thus far, based on the function of the $\mathrm{CP}$ and the role of the $\mathrm{C} 1$ complex in immune complex clearance, inhibition of the proximal part of the CP could increase the risk of symptoms found in immune complex diseases, as is observed in patients with congenital $\mathrm{CP}$ deficiencies (C1q, C1r, C1s, C2, and C4) [88]. To date, there are no clinical data that support this hypothesis, but this should be closely monitored.

Altogether, these arguments have nourished the search for additional therapeutics, which may target complement inhibition upstream of $\mathrm{C} 5$ at a target that is specific for the disease, facilitate more convenient non-intravenous routes of administration, and/or facilitate prolonged dose intervals due to increased half-life. To conclude this review, we will discuss novel potential targets, provide an overview of the complement therapeutics currently in the pipeline, and discuss their 
potential for the treatment of AIHA and PNH (for a full overview of agents in the pipeline, see Table 2 and Fig. 3).

\section{Developments in the complement field}

In order to reduce extravascular hemolysis, an obvious direction for drug discovery lies in targeting the complement system at the level of C3. By targeting at this level, the opsonization of RBCs and subsequent phagocytosis can be prevented. Targeting complement at the $\mathrm{C} 3$ level has a clear benefit in that it allows for the targeting of all different activation pathways simultaneously, as these come together at the C3 level. Thus, complete inhibition of complement activity would be possible, if desired [136]. The main therapeutic candidates for the inhibition of $\mathrm{C} 3$ are compstatin and its analogs. Compstatin is a cyclic tridecapeptide, originally found in a random peptide library upon screening for $\mathrm{C} 3 \mathrm{~b}$ binding, which showed to have direct $\mathrm{C} 3$ inhibiting properties [137]. Ever since, several analogs of compstatin have been developed in order to optimize production, pharmacokinetics, and delivery of the drug $[136,138]$. Compstatin analog Cp40 has been shown to prevent hemolysis and opsonization of $\mathrm{PNH}$ RBCs and inhibition of intravascular and extravascular hemolysis in AIHA serum in vitro $[139,140]$. Up to date, pegcetacoplan (formerly APL-2), a pegylated compstatin analog suitable for subcutaneous administration, has been deemed safe in phase I clinical trial. Currently, a phase II trial is on its way for the usage of pegcetacoplan in AIHA (ClinicalTrials.gov: NCT03226678), as well as a phase III trial for PNH (ClinicalTrials.gov: NCT04085601). The subcutaneous administration likely implicates a significant reduction in patient burden. However, it may come at the cost of infectious complications, as C3 blocking both halts opsonization and terminal complement activation. C3 deficient patients suffer from recurring bacterial infections, but to what extent this corresponds to a pharmacologically induced C3 deficiency remains to be determined [141].

There are certain therapeutics in development that target the CP and/or LP specifically. Since in AIHA the CP is the main route of complement activation, blocking the $\mathrm{CP}$ is an appealing alternative to blocking $\mathrm{C} 5$. The first drug used to target the $\mathrm{CP} / \mathrm{LP}$ is recombinant or plasma-purified $\mathrm{C} 1-\mathrm{INH}$, which is approved for usage in hereditary and acquired angioedema, where patients suffer from C1-INH deficiency [142]. As described previously, C1-INH was successful in a patient with refractory AIHA based on a single-case report [80]. Currently, a phase II clinical study is underway in AIHA patients (ClinicalTrialsRegister.eu: 2012-003710-13/NL). The $\mathrm{CP}$ can also be targeted at other levels, using sutimlimab and BIVV020 to inhibit $\mathrm{C} 1 \mathrm{~s}$ and thus prevent $\mathrm{C} 2$ cleavage as described previously, or by using an $\mathrm{mAb}$ against $\mathrm{C} 2$ directly $[86,87,97]$. C2 especially is a promising target to block the $\mathrm{CP}$ and $\mathrm{LP}$, as it has the lowest concentration of the $\mathrm{CP}$ and $\mathrm{LP}$ components and would therefore potentially require lower and/or less frequent dosage of inhibitors [8]. A recent study described ARGX-117 as an inhibiting mAb against $\mathrm{C} 2$, which successfully inhibited $\mathrm{CP}$ activity in cynomolgus monkeys [97].

Next to specific targeting of the CP, several therapeutics are in development to specifically inhibit the AP. This seems especially of interest for $\mathrm{PNH}$, which is mainly a disorder of the AP. A benefit of targeting the AP is that an infection can still be cleared with the help of the complement system via the LP or CP, thus potentially reducing infection risk [143]. Furthermore, $\mathrm{C} 3 \mathrm{~b}$ opsonization could potentially be slowed down by inhibiting the AP, which would reduce extravascular hemolysis. Interestingly, there are a few therapeutics in the pipeline that can be administered orally and target FB, FD, or properdin. FD can be targeted in two ways: either by inhibiting FD directly or by inhibiting MASP3, which cleaves pro-factor D into FD. Properdin stabilizes the AP C3 convertase and thereby extends its activity [8]. Conversely, inhibiting properdin does not completely block $\mathrm{C} 3$ convertase formation but rather shortens its activity [144]. Inhibition of the $\mathrm{AP}$ as a mechanism of action has been demonstrated to be effective in animal models of antibody-induced arthritis and membranous nephropathy, and several clinical trials in $\mathrm{PNH}$ are currently in progress [126]. Especially, LNP023 (ClinicalTrials.gov: NCT03439839), ACH-5228 (ClinicalTrials.gov: NCT03439839), danicopan (ClinicalTrials.gov: NCT04170023), and BCX9930 (ClinicalTrials.gov: NCT04469645) are of particular interest as these can be administered orally (Table 2). If successful, these oral administration routes could open up novel possibilities of complementtargeting treatment with a limited patient burden.

Another way of inhibiting complement activity while minimizing the infection risk is by utilizing mechanisms of complement regulators, which guard against dysregulated complement activation. Several recombinant proteins that mimic (parts of) complement regulators are in development [141]. An example is TT30, a FH and CR2 fusion protein designed to inhibit the AP at sites of complement activation. The CR2 domains bind to the $\mathrm{C} 3 \mathrm{~b}$ fragments at sites of complement activation, where the FH domains can then fulfill their regulatory function [102]. In vitro, TT30 inhibited complementmediated hemolysis and $\mathrm{C} 3 \mathrm{~b}$ opsonization of PNH RBCs, while in vivo studies in monkeys have shown almost complete inhibition of the AP and partial inhibition of the CP upon subcutaneous TT30 administration [102, 103]. A phase I trial for TT30 in PNH however was recently terminated, as the enrollment criteria could not be met (ClinicalTrials.gov, NCT01335165). Another interesting approach is the potentiation or suppletion of fluid-phase complement regulators, such as FH and FI, which could seriously reduce AP activity and thus aid in the reduction of both intravascular and extravascular hemolysis [135]. An interesting example 


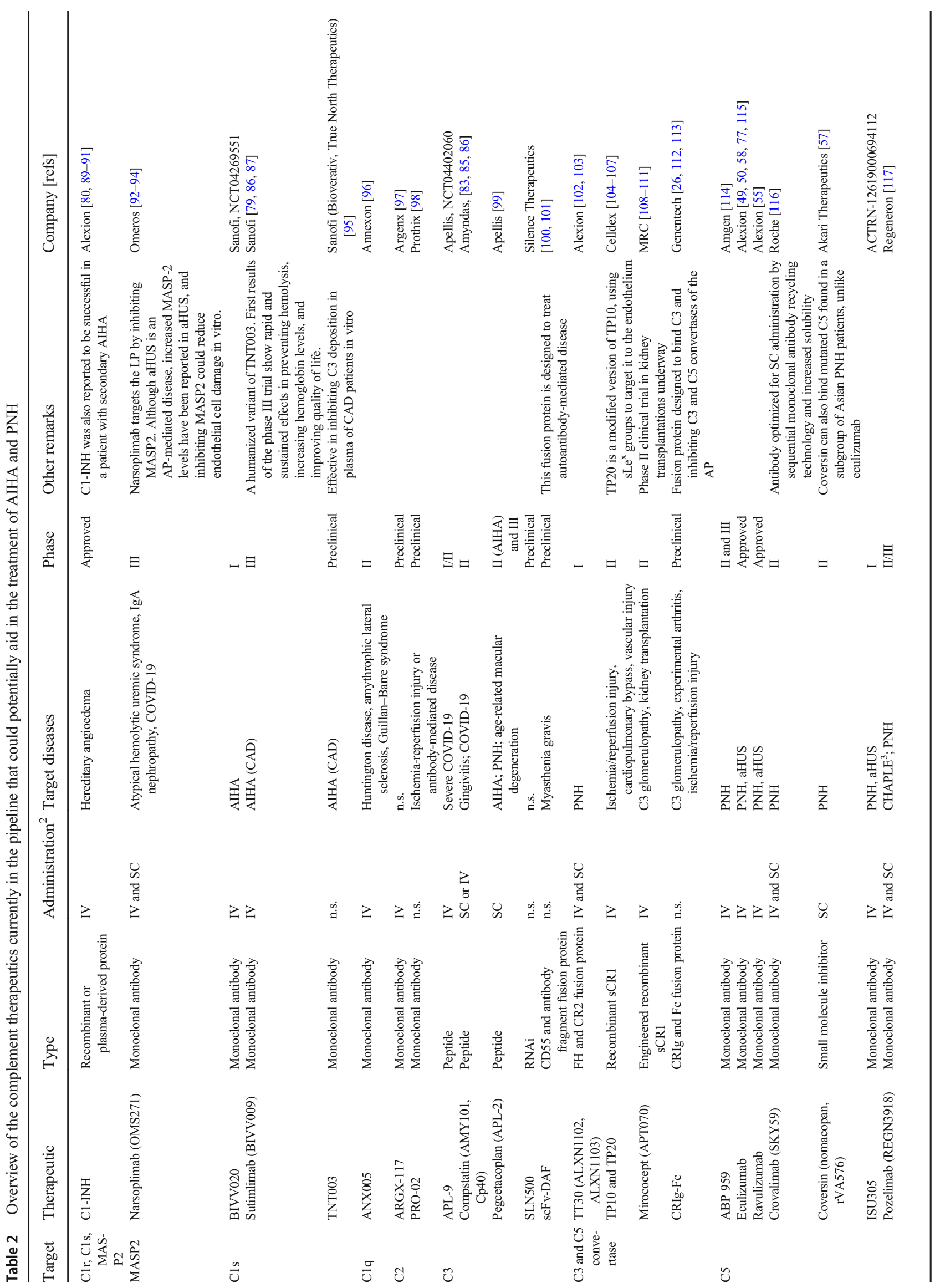




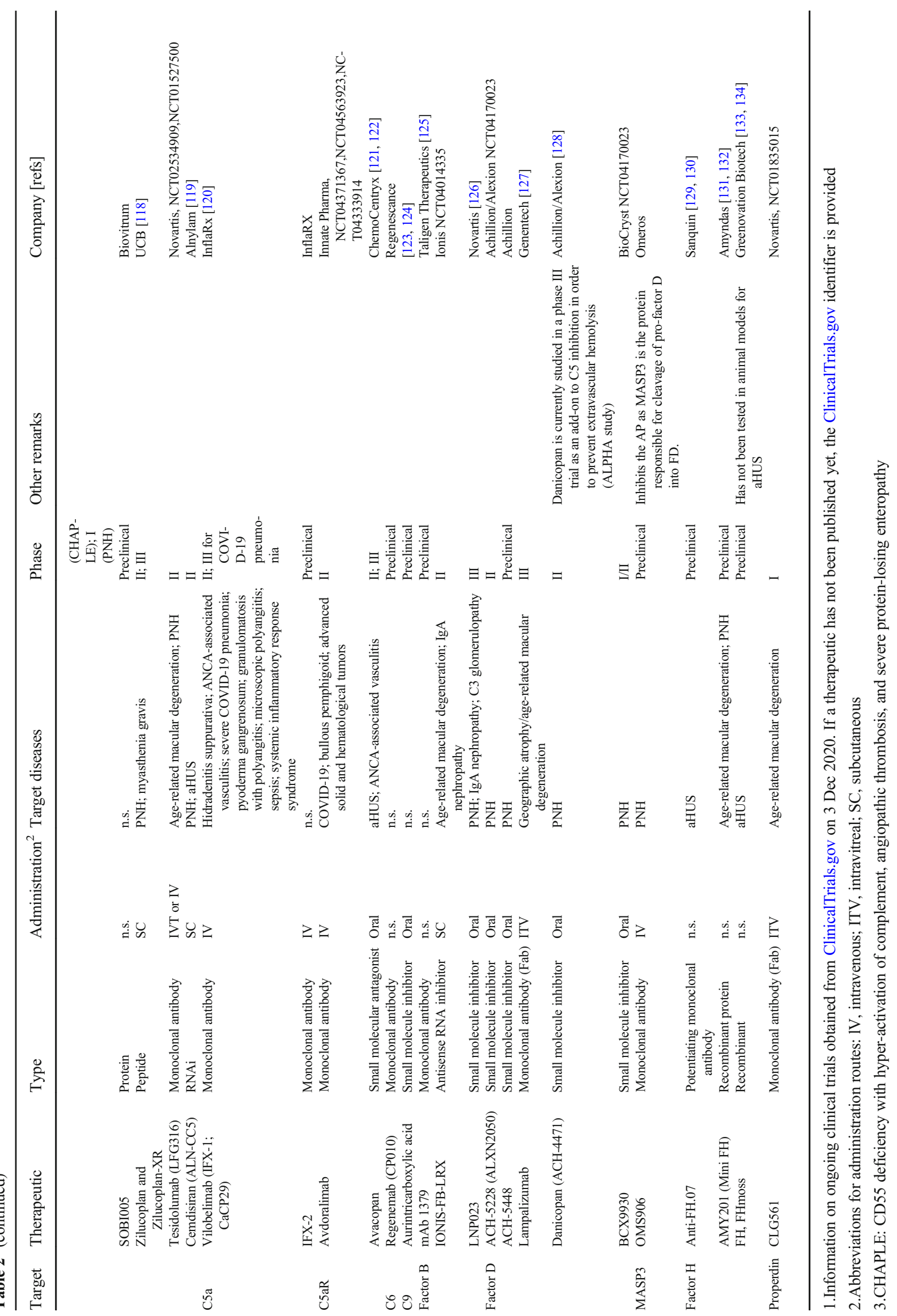




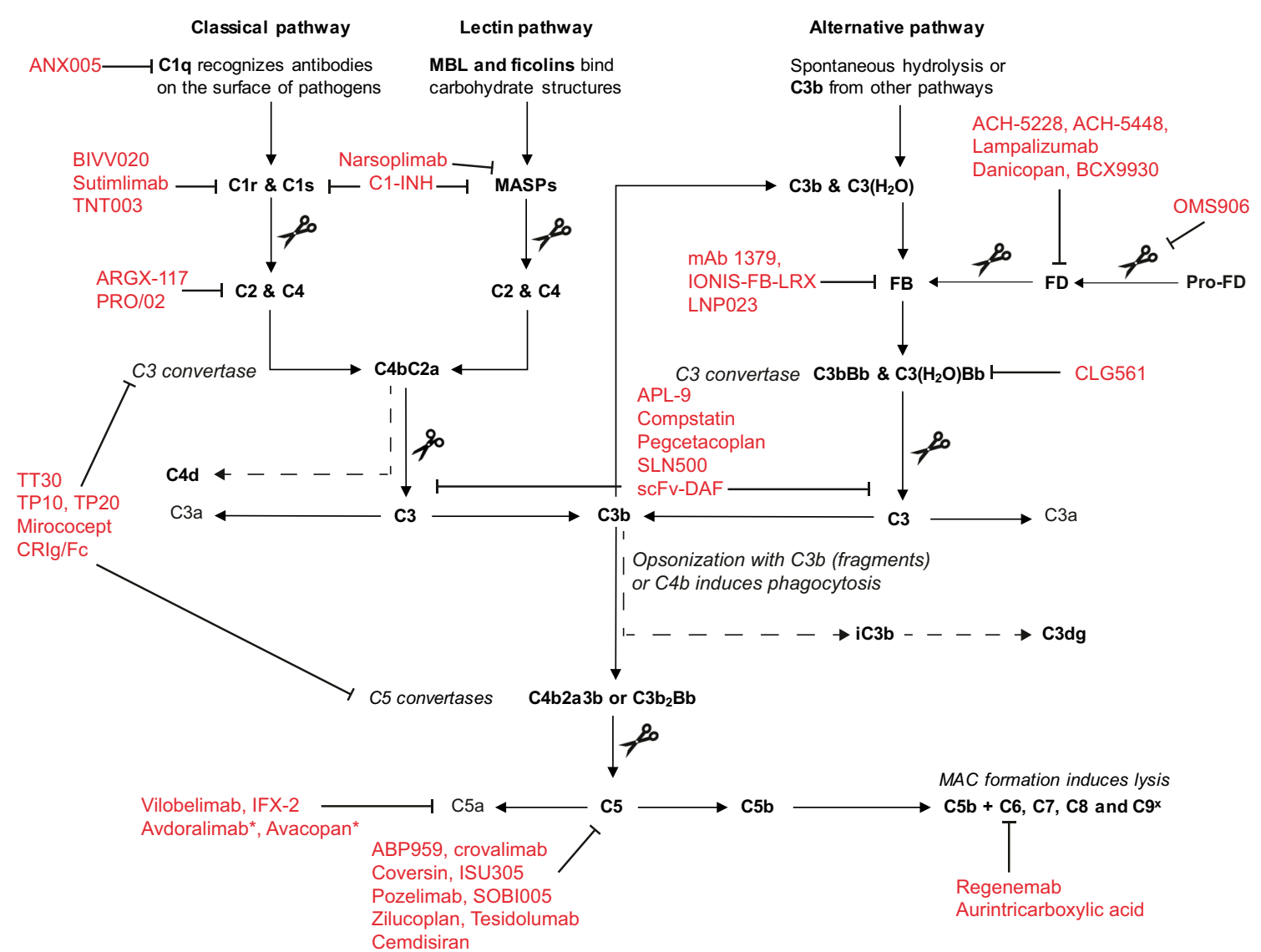

Fig 3 The complement system and targets of novel complement therapeutics. This overview shows the current drug developing landscape for AIHA and PNH. Scissors indicate the cleavage of a

is a potentiating antibody, anti-FH.07, that has been developed for $\mathrm{FH}$ [129]. As this is an AP regulator, potentiating FH would mainly be of interest in PNH. Anti-FH.07 has already been shown to be able to enhance the function of mutated FH in vitro on RBCs [130].

Finally, several novel treatments that target the terminal complement pathway, similar to eculizumab and ravulizumab, are in development. Although their clinical effect and application are probably similar to that of the currently approved therapeutics, these new therapeutics are designed to simplify the administration, which will increase convenience and compliance to therapy and may reduce costs. Coversin, crovalimab, zilucoplan, and cemdisiran (all in phase II trials) are all C5 inhibitors that can be administered subcutaneously [57, 116, 118, 119]. Lastly, aurintricarboxylic acid is a $\mathrm{C} 9$ small molecule inhibitor that can be taken orally and was effective in inhibiting hemolysis of PNH RBCs in vitro [123, 145].

\section{Concluding remarks}

The success stories of eculizumab and ravulizumab have shown that there is a need for drugs that specifically protein by a protease. Dotted lines indicate the breakdown of proteins. Figure adapted from [135]. *These drugs do not directly target C5a but rather the $\mathrm{C} 5 \mathrm{a}$ receptor $\mathrm{C} 5 \mathrm{aR}$

target activated complement components that can be subcutaneously or orally administered in diseases in which the RBC is a target of the complement system. For almost all complement components, there is currently a specific drug available or in development, which will have an immense impact on the therapeutic approach to rare complement-mediated diseases, including those of the RBC such as PNH and AIHA. Optimizing complement-targeting therapies in terms of safety and convenience will further improve therapeutic options and will have an immense impact on the therapeutic approach of rare complement-mediated hemolysis.

Abbreviations $A P$, alternative pathway; $A I H A$, autoimmune hemolytic anemia; $C A D$, cold agglutinin disease; $C A S$, cold agglutinin syndrome; $C P$, classical pathway; $D A T$, direct antiglobulin test; $F B$, factor $\mathrm{B} ; F H$, factor $\mathrm{H} ; F I$, factor I; $L P$, lectin pathway; $M A C$, membrane attack complex; $P C H$, paroxysmal cold hemoglobinuria; $P I G A$, phosphatidylinositol glycan-A; $P N H$, paroxysmal nocturnal hemoglobinuria; $R B C$, red blood cell

Author contribution MJ, EdB, MQ, DE, JdV, SZ, MdH, and IJ wrote the manuscript and approved the final version. EdB drafted the figures. $\mathrm{MdH}$ and IJ obtained funding. 
Funding This work is part of the research program Aspasia with project number 015.014.069, which is (partly) financed by the Netherlands Organisation for Scientific Research (NWO) to IJ. In addition, this work was funded by the Product and Process Development grants obtained (in competition) from Sanquin Blood Supply Foundation: PPOD 105 to IJ and PPOC-15-27 to MdH.

\section{Declarations}

Conflict of interest The authors declare no competing interests.

Open Access This article is licensed under a Creative Commons Attribution 4.0 International License, which permits use, sharing, adaptation, distribution and reproduction in any medium or format, as long as you give appropriate credit to the original author(s) and the source, provide a link to the Creative Commons licence, and indicate if changes were made. The images or other third party material in this article are included in the article's Creative Commons licence, unless indicated otherwise in a credit line to the material. If material is not included in the article's Creative Commons licence and your intended use is not permitted by statutory regulation or exceeds the permitted use, you will need to obtain permission directly from the copyright holder. To view a copy of this licence, visit http://creativecommons.org/licenses/by/4.0/.

\section{References}

1. Schröder-Braunstein J, Kirschfink M (2019) Complement deficiencies and dysregulation: pathophysiological consequences, modern analysis, and clinical management. Mol Immunol 114: 299-311. https://doi.org/10.1016/j.molimm.2019.08.002

2. Flegel WA (2015) Pathogenesis and mechanisms of antibodymediated hemolysis. Transfusion 55:S47-S58. https://doi.org/10. 1111/trf.13147

3. Young NS, Meyers G, Schrezenmeier H, Hillmen P, Hill A (2009) The management of paroxysmal nocturnal hemoglobinuria: recent advances in diagnosis and treatment and new hope for patients. Semin Hematol 46:S1-S16. https://doi.org/10.1053/j. seminhematol.2008.11.004

4. Barcellini W, Fattizzo B, Zaninoni A (2018) Current and emerging treatment options for autoimmune hemolytic anemia. Expert Rev Clin Immunol 14:857-872. https://doi.org/10.1080/ 1744666X.2018.1521722

5. Raina R, Krishnappa V, Blaha T, Kann T, Hein W, Burke L, Bagga A (2019) Atypical hemolytic-uremic syndrome: an update on pathophysiology, diagnosis, and treatment. Ther Apher Dial 23:4-21. https://doi.org/10.1111/1744-9987.12763

6. Zipfel PF, Skerka C (2009) Complement regulators and inhibitory proteins. Nat Rev Immunol 9:729-740. https://doi.org/10.1038/ nri2620

7. Hajishengallis G, Reis ES, Mastellos DC, Ricklin D, Lambris JD (2017) Novel mechanisms and functions of complement. Nat Immunol 18:1288-1298. https://doi.org/10.1038/ni.3858

8. Merle NS, Church SE, Fremeaux-Bacchi V, Roumenina LT (2015) Complement system part I - molecular mechanisms of activation and regulation. Front Immunol 6:1-30

9. Merle NS, Noe R, Halbwachs-Mecarelli L, Fremeaux-Bacchi V, Roumenina LT (2015) Complement system part II: role in immunity. Front Immunol 6:1-26. https://doi.org/10.3389/fimmu.2015. 00257

10. Reis ES, Mastellos DC, Hajishengallis G, Lambris JD (2019) New insights into the immune functions of complement. Nat Rev Immunol 19:503-516
11. Mathern DR, Heeger PS (2015) Molecules great and small: the complement system. Clin J Am Soc Nephrol 10:1636-1650. https://doi.org/10.2215/CJN.06230614

12. Garred P, Genster N, Pilely K, Bayarri-Olmos R, Rosbjerg A, Ma YJ, Skjoedt MO (2016) A journey through the lectin pathway of complement-MBL and beyond. Immunol Rev 274:74-97. https://doi.org/10.1111/imr.12468

13. Ricklin D, Hajishengallis G, Yang K, Lambris JD (2010) Complement: a key system for immune surveillance and homeostasis. Nat Immunol 11:785-797. https://doi.org/10.1038/ni.1923

14. Strainic MG, Liu J, Huang D, An F, Lalli PN, Muqim N, Shapiro VS, Dubyak GR, Heeger PS, Medof ME (2008) Locally produced complement fragments $\mathrm{C} 5 \mathrm{a}$ and $\mathrm{C} 3 \mathrm{a}$ provide both costimulatory and survival signals to naive CD4+ T cells. Immunity 28:425435. https://doi.org/10.1016/j.immuni.2008.02.001

15. van Lookeren CM, Wiesmann C, Brown EJ (2007) Macrophage complement receptors and pathogen clearance. Cell Microbiol 9: 2095-2102. https://doi.org/10.1111/j.1462-5822.2007.00981.x

16. Holers VM, Kulik L (2007) Complement receptor 2, natural antibodies and innate immunity: inter-relationships in B cell selection and activation. Mol Immunol 44:64-72. https://doi.org/10.1016/j. molimm.2006.07.003

17. Vorup-Jensen T, Jensen RK (2018) Structural immunology of complement receptors 3 and 4. Front Immunol 9:1-20. https:// doi.org/10.3389/fimmu.2018.02716

18. Helmy KY, Katschke KJ, Gorgani NN et al (2006) CRIg: a macrophage complement receptor required for phagocytosis of circulating pathogens. Cell 124:915-927. https://doi.org/10.1016/j.cell. 2005.12.039

19. He JQ, Wiesmann C, van Lookeren CM (2008) A role of macrophage complement receptor CRIg in immune clearance and inflammation. Mol Immunol 45:4041-4047. https://doi.org/10. 1016/j.molimm.2008.07.011

20. Small AG, Al-Baghdadi M, Quach A et al (2016) Complement receptor immunoglobulin: a control point in infection and immunity, inflammation and cancer. Swiss Med Wkly 146:w14301. https://doi.org/10.4414/smw.2016.14301

21. Java A, Liszewski MK, Hourcade DE, Zhang F, Atkinson JP (2015) Role of complement receptor 1 (CR1; CD35) on epithelial cells: a model for understanding complement-mediated damage in the kidney. Mol Immunol 67:584-595. https://doi.org/10.1016/j. molimm.2015.07.016

22. Khera R, Das N (2009) Complement receptor 1: disease associations and therapeutic implications. Mol Immunol 46:761-772

23. Liszewski MK, Kemper C (2019) Complement in motion: the evolution of CD46 from a complement regulator to an orchestrator of normal cell physiology. J Immunol 203:3-5. https://doi.org/10. 4049/jimmunol.1900527

24. Yamamoto H, Fara AF, Dasgupta P, Kemper C (2013) CD46: The "multitasker" of complement proteins. Int J Biochem Cell Biol 45: 2808-2820. https://doi.org/10.1016/j.biocel.2013.09.016

25. Thielen AJF, Zeerleder S, Wouters D (2018) Consequences of dysregulated complement regulators on red blood cells. Blood Rev:0-1. https://doi.org/10.1016/j.blre.2018.01.003

26. Katschke KJ, Helmy KY, Steffek M et al (2007) A novel inhibitor of the alternative pathway of complement reverses inflammation and bone destruction in experimental arthritis. J Exp Med 204: 1319-1325. https://doi.org/10.1084/jem.20070432

27. Davis AE, Mejia P, Lu F (2008) Biological activities of C1 inhibitor. Mol Immunol 45:4057-4063

28. Hovingh ES, van den Broek B, Jongerius I (2016) Hijacking complement regulatory proteins for bacterial immune evasion. Front Microbiol 7:1-20. https://doi.org/10.3389/fmicb.2016.02004

29. Blaum BS, Hannan JP, Herbert AP, Kavanagh D, Uhrín D, Stehle $\mathrm{T}$ (2015) Structural basis for sialic acid-mediated self-recognition 
by complement factor $\mathrm{H}$. Nat Chem Biol 11:77-82. https://doi. org/10.1038/nchembio.1696

30. Parente R, Clark SJ, Inforzato A, Day AJ (2017) Complement factor $\mathrm{H}$ in host defense and immune evasion. Cell Mol Life Sci $74: 1605-1624$

31. Nilsson SC, Sim RB, Lea SM, Fremeaux-Bacchi V, Blom AM (2011) Complement factor I in health and disease. Mol Immunol 48:1611-1620

32. Lachmann PJ (2019) The story of complement factor I. Immunobiology 224:511-517. https://doi.org/10.1016/j.imbio. 2019.05.003

33. Dempsey PW, Allison MED, Akkaraju S, Goodnow CC, Fearon DT (1996) C3d of complement as a molecular adjuvant: bridging innate and acquired immunity. Science 271:348-350. https://doi. org/10.1126/science.271.5247.348

34. Toapanta FR, Ross TM (2006) Complement-mediated activation of the adaptive immune responses: role of $\mathrm{C} 3 \mathrm{~d}$ in linking the innate and adaptive immunity. Immunol Res 36:197-210. https://doi.org/10.1385/IR:36:1:197

35. Koenderman L (2019) Inside-out control of Fc-receptors. Front Immunol 10:1-11. https://doi.org/10.3389/fimmu.2019.00544

36. de Taeye SW, Rispens T, Vidarsson G (2019) The ligands for human IgG and their effector functions. Antibodies 8:30. https:// doi.org/10.3390/antib8020030

37. Mkaddem S Ben, Benhamou M, Monteiro RC (2019) Understanding Fc receptor involvement in inflammatory diseases: from mechanisms to new therapeutic tools. Front Immunol 10:. https://doi.org/10.3389/fimmu.2019.00811

38. Schreiber AD, Frank MM (1972) Role of antibody and complement in the immune clearance and destruction of erythrocytes. J Clin Invest 51:583-589. https://doi.org/10.1172/JCI106847

39. Nagelkerke SQ, Bruggeman CW, Den Haan JMM et al (2018) Red pulp macrophages in the human spleen are a distinct cell population with a unique expression of $\mathrm{Fc}-\mathrm{g}$ receptors. Blood Adv 2:941-963. https://doi.org/10.1182/bloodadvances. 2017015008

40. Ehlenberger AG, Nussenzweig V (1977) The role of membrane receptors for C3b and C3d in phagocytosis. J Exp Med 145:357371

41. Atkinson JP, Frank MM (1974) Complement-independent Clearance of IgG-sensitized erythrocytes: inhibition by cortisone. Blood 44:629-637

42. Taylor RP, Lindorfer MA (2018) Mechanisms of complementmediated damage in hematological disorders. Semin Hematol 55:118-123. https://doi.org/10.1053/j.seminhematol.2018.02.003

43. Sakari Jokiranta T (2017) HUS and atypical HUS. Blood 129: 2847-2856. https://doi.org/10.1182/blood-2016-11-709865.to

44. Chen JY, Galwankar NS, Emch HN, Menon SS, Cortes C, Thurman JM, Merrill SA, Brodsky RA, Ferreira VP (2020) Properdin is a key player in lysis of red blood cells and complement activation on endothelial cells in hemolytic anemias caused by complement dysregulation. Front Immunol 11:1-21. https:// doi.org/10.3389/fimmu.2020.01460

45. Hill A, Dezern AE, Kinoshita T, Brodsky RA (2017) Paroxysmal nocturnal haemoglobinuria. Nat Rev Dis Prim 3

46. Brodsky R (2014) Paroxysmal nocturnal hemoglobinuria. Blood 124:2804-2811. https://doi.org/10.11406/rinketsu.53.15

47. Ferreira VP, Pangburn MK (2007) Factor H-mediated cell surface protection from complement is critical for the survival of $\mathrm{PNH}$ erythrocytes. Blood 110:2190-2192. https://doi.org/10.1182/ blood-2007-04-083170

48. Kokoris SI, Gavriilaki E, Miari A, Travlou A, Kyriakou E, Anagnostopoulos A, Grouzi E (2018) Renal involvement in paroxysmal nocturnal hemoglobinuria: an update on clinical features, pathophysiology and treatment. Hematology 23:558-566. https:// doi.org/10.1080/10245332.2018.1444563
49. Socié G, Caby-Tosi MP, Marantz JL, Cole A, Bedrosian CL, Gasteyger C, Mujeebuddin A, Hillmen P, Vande Walle J, Haller $H$ (2019) Eculizumab in paroxysmal nocturnal haemoglobinuria and atypical haemolytic uraemic syndrome: 10-year pharmacovigilance analysis. Br J Haematol 185:297-310. https://doi.org/10.1111/bjh.15790

50. Rother RP, Rollins SA, Mojcik CF, Brodsky RA, Bell L (2007) Discovery and development of the complement inhibitor eculizumab for the treatment of paroxysmal nocturnal hemoglobinuria. Nat Biotechnol 25:1256-1264. https://doi.org/10.1038/ nbt1344

51. Hillmen P, Young NS, Schubert J, Brodsky RA, Socié G, Muus P, Röth A, Szer J, Elebute MO, Nakamura R, Browne P, Risitano AM, Hill A, Schrezenmeier H, Fu CL, Maciejewski J, Rollins SA, Mojcik CF, Rother RP, Luzzatto L (2006) The complement inhibitor eculizumab in paroxysmal nocturnal hemoglobinuria. N Engl J Med 355:1233-1243. https://doi.org/10.1056/NEJMoa061648

52. Brodsky RA, Young NS, Antonioli E, Risitano AM, Schrezenmeier H, Schubert J, Gaya A, Coyle L, de Castro C, Fu CL, Maciejewski JP, Bessler M, Kroon HA, Rother RP, Hillmen P (2008) Multicenter phase 3 study of the complement inhibitor eculizumab for the treatment of patients with paroxysmal nocturnal hemoglobinuria. Blood 111:1840-1847. https:// doi.org/10.1182/blood-2007-06-094136

53. Kelly RJ, Hill A, Arnold LM, Brooksbank GL, Richards SJ Cullen M, Mitchell LD, Cohen DR, Gregory WM, Hillmen P (2011) Long-term treatment with eculizumab in paroxysmal nocturnal hemoglobinuria: sustained efficacy and improved survival. Blood 117:6786-6792. https://doi.org/10.1182/blood-2011-02333997

54. Lee JW, de Fontbrune FS, Lee LWL et al (2019) Ravulizumab (ALXN1210) vs eculizumab in adult patients with PNH naive to complement inhibitors: the 301 study. Blood 133:530-539. https://doi.org/10.1182/blood-2018-09-876136

55. Kulasekararaj AG, Hill A, Rottinghaus ST, Langemeijer S, Wells R, Gonzalez-Fernandez FA, Gaya A, Lee JW, Gutierrez EO, Piatek CI, Szer J, Risitano A, Nakao S, Bachman E, Shafner L, Damokosh AI, Ortiz S, Röth A, Peffault de Latour R (2019) Ravulizumab (ALXN1210) vs eculizumab in C5-inhibitor-experienced adult patients with PNH: the 302 study. Blood 133:540 549. https://doi.org/10.1182/blood-2018-09-876805

56. Nishimura JI, Yamamoto M, Hayashi S, Ohyashiki K, Ando K, Brodsky AL, Noji H, Kitamura K, Eto T, Takahashi T, Masuko M, Matsumoto T, Wano Y, Shichishima T, Shibayama H, Hase M, Li L, Johnson K, Lazarowski A, Tamburini P, Inazawa J, Kinoshita T, Kanakura Y (2014) Genetic variants in C5 and poor response to eculizumab. N Engl J Med 370:632-639. https://doi. org/10.1056/NEJMoa1311084

57. Schols S, Nunn MA, Mackie I, Weston-Davies W, Nishimura JI, Kanakura Y, Blijlevens N, Muus P, Langemeijer S (2020) Successful treatment of a PNH patient non-responsive to eculizumab with the novel complement $\mathrm{C} 5$ inhibitor coversin (nomacopan). Br J Haematol 188:334-337. https://doi.org/10. 1111/bjh. 16305

58. Risitano AM, Notaro R, Marando L, Serio B, Ranaldi D, Seneca E, Ricci P, Alfinito F, Camera A, Gianfaldoni G, Amendola A, Boschetti C, di Bona E, Fratellanza G, Barbano F, Rodeghiero F, Zanella A, Iori AP, Selleri C, Luzzatto L, Rotoli B (2009) Complement fraction 3 binding on erythrocytes as additional mechanism of disease in paroxysmal nocturnal hemoglobinuria patients treated by eculizumab. Blood 113:4094-4100. https:// doi.org/10.1182/blood-2008-11-189944

59. Notaro R, Sica M (2018) C3-mediated extravascular hemolysis in PNH on eculizumab: mechanism and clinical implications. Semin Hematol 55:130-135. https://doi.org/10.1053/j.seminhematol. 2018.05.014 
60. Rondelli T, Risitano AM, de Latour RP, Sica M, Peruzzi B, Ricci P, Barcellini W, Iori AP, Boschetti C, Valle V, Fremeaux-Bacchi V, de Angioletti M, Socie G, Luzzatto L, Notaro R (2014) Polymorphism of the complement receptor 1 gene correlates with the hematologic response to eculizumab in patients with paroxysmal nocturnal hemoglobinuria. Haematologica 99:262-266. https://doi.org/10.3324/haematol.2013.090001

61. Risitano AM, Marotta S, Ricci P, Marano L, Frieri C, Cacace F, Sica M, Kulasekararaj A, Calado RT, Scheinberg P, Notaro R, Peffault de Latour R (2019) Anti-complement treatment for paroxysmal nocturnal hemoglobinuria: time for proximal complement inhibition? A position paper from the SAAWP of the EBMT. Front Immunol 10. https://doi.org/10.3389/fimmu.2019. 01157

62. Barcellini W, Fattizzo B, Zaninoni A, Radice T, Nichele I, di Bona E, Lunghi M, Tassinari C, Alfinito F, Ferrari A, Leporace AP, Niscola P, Carpenedo M, Boschetti C, Revelli N, Villa MA, Consonni D, Scaramucci L, de Fabritiis P, Tagariello G, Gaidano G, Rodeghiero F, Cortelezzi A, Zanella A (2014) Clinical heterogeneity and predictors of outcome in primary autoimmune hemolytic anemia: a GIMEMA study of 308 patients. Blood 124:2930-2936. https://doi.org/10.1182/blood-2014-06583021

63. Zanella A, Barcellini W (2014) Treatment of autoimmune hemolytic anemias. Haematologica 99:1547-1554. https://doi.org/10. 3324/haematol.2014.114561

64. Go RS, Winters JL, Kay NE (2017) How I treat autoimmune hemolytic anemia. Blood 129:2971-2979. https://doi.org/10. 1182/blood-2016-11-693689

65. Jäger U, Barcellini W, Broome CM, Gertz MA, Hill A, Hill QA, Jilma B, Kuter DJ, Michel M, Montillo M, Röth A, Zeerleder SS, Berentsen S (2020) Diagnosis and treatment of autoimmune hemolytic anemia in adults: recommendations from the First International Consensus Meeting. Blood Rev 41:100648. https:// doi.org/10.1016/j.blre.2019.100648

66. Berentsen S, Hill A, Hill QA, Tvedt THA, Michel M (2019) Novel insights into the treatment of complement-mediated hemolytic anemias. Ther Adv Vaccines 10:1-20. https://doi.org/10.1177/ 2040620719873321

67. Berentsen S, Beiske K, Tjønnfjord GE (2007) Primary chronic cold agglutinin disease: an update on pathogenesis, clinical features and therapy. Hematology 12:361-370. https://doi.org/10. 1080/10245330701445392

68. Meulenbroek EM, de Haas M, Brouwer C, Folman C, Zeerleder SS, Wouters D (2015) Complement deposition in autoimmune hemolytic anemia is a footprint for difficult-to-detect IgM autoantibodies. Haematologica 100:1407-1414. https://doi.org/10.3324/ haematol.2015.128991

69. Berentsen S, Tjønnfjord GE (2012) Diagnosis and treatment of cold agglutinin mediated autoimmune hemolytic anemia. Blood Rev 26:107-115. https://doi.org/10.1016/j.blre.2012.01.002

70. Gullipalli D, Zhang F, Sato S, Ueda Y, Kimura Y, Golla M, Miwa T, Wang J, Song WC (2018) Antibody inhibition of properdin prevents complement-mediated intravascular and extravascular hemolysis. J Immunol 201:1021-1029. https://doi.org/10.4049/ jimmunol.1800384

71. Lin Z, Schmidt CQ, Koutsogiannaki S, Ricci P, Risitano AM, Lambris JD, Ricklin D (2015) Complement C3dg-mediated erythrophagocytosis: Implications for paroxysmal nocturnal hemoglobinuria. Blood 126:891-894. https://doi.org/10.1182/ blood-2015-02-625871

72. Berentsen S (2014) Complement, cold agglutinins, and therapy. Red Cells, Iron Erythrop 123:4010-4012

73. Shanbhag S, Spivak J (2015) Paroxysmal cold hemoglobinuria. Hematol Oncol Clin North Am 29:473-478. https://doi.org/10. 1016/j.hoc.2015.01.004
74. Berentsen S, Sundic T $(2015,2015)$ Red blood cell destruction in autoimmune hemolytic anemia: role of complement and potential new targets for therapy. Biomed Res Int:1-11. https://doi.org/10. $1155 / 2015 / 363278$

75. Berentsen S, Randen U, Oksman M, Birgens H, Tvedt THA, Dalgaard J, Galteland E, Haukås E, Brudevold R, Sørbø JH, Næss IA, Malecka A, Tjønnfjord GE (2017) Bendamustine plus rituximab for chronic cold agglutinin disease: results of a Nordic prospective multicenter trial. Blood 130:537-541. https://doi.org/ 10.1182/blood-2017-04-778175

76. Berentsen S (2018) Complement activation and inhibition in autoimmune hemolytic anemia: focus on cold agglutinin disease. Semin Hematol 55:141-149. https://doi.org/10.1053/j. seminhematol.2018.04.002

77. Röth A, Bommer M, Huttmann A et al (2018) Eculizumab in cold agglutinin disease (DECADE): an open-label, prospective, bicentric, nonrandomized phase 2 trial. Blood Adv 2:25432549. https://doi.org/10.1182/bloodadvances.2018024190

78. Makishima K, Obara N, Ishitsuka K, Sukegawa S, Suma S, Kiyoki Y, Baba N, Sakamoto T, Kato T, Kusakabe M, Nishikii H, Kurita N, Yokoyama Y, Sakata-Yanagimoto M, Hasegawa Y, Chiba S (2019) High efficacy of eculizumab treatment for fulminant hemolytic anemia in primary cold agglutinin disease. Ann Hematol 98:1031-1032. https://doi.org/10.1007/s00277-0183521-4

79. Röth A, Barcellini W, D'Sa S et al (2019) Inhibition of complement $\mathrm{C} 1 \mathrm{~s}$ with sutimlimab in patients with cold agglutinin disease (CAD): results from the phase 3 Cardinal study. Blood 134:LBA2. https://doi.org/10.1182/blood-2019-132490

80. Wouters D, Stephan F, Strengers P, de Haas M, Brouwer C, Hagenbeek A, van Oers MHJ, Zeerleder S (2013) C1-esterase inhibitor concentrate rescues erythrocytes from complementmediated destruction in autoimmune hemolytic anemia. Blood 121:1242-1244

81. Tesfaye A, Broome C (2016) A novel approach for treatment of cold agglutinin syndrome-related severe hemolysis. J Hematol 5: 30-33. https://doi.org/10.14740/jh242w

82. Koppel A, Lim S, Osby M, Garratty G, Goldfinger D (2007) Rituximab as successful therapy in a patient with refractory paroxysmal cold hemoglobinuria. Transfusion 47:1902-1904. https://doi.org/10.1111/j.1537-2995.2007.01414.x

83. Gregory GP, Opat S, Quach H, Shortt J, Tran H (2011) Failure of eculizumab to correct paroxysmal cold hemoglobinuria. Ann Hematol 90:989-990. https://doi.org/10.1007/s00277-010-1123-x

84. Lau-Braunhut SA, Stone H, Collins G, Berentsen S, Braun BS, Zinter MS (2019) Paroxysmal cold hemoglobinuria successfully treated with complement inhibition. Blood Adv 3:3575-3578. https://doi.org/10.1182/bloodadvances.2019000897

85. Patriquin CJ, Kiss T, Caplan S, Chin-Yee I, Grewal K, Grossman J, Larratt L, Marceau D, Nevill T, Sutherland DR, Wells RA, Leber B (2019) How we treat paroxysmal nocturnal hemoglobinuria: a consensus statement of the Canadian PNH Network and review of the national registry. Eur J Haematol 102:36-52. https:// doi.org/10.1111/ejh.13176

86. Gelbenegger G, Schoergenhofer C, Derhaschnig U, Buchtele N, Sillaber C, Fillitz M, Schenk TM, D'Sa S, Cartwright R, Gilbert JC, Jilma B, Jaeger U (2020) Inhibition of complement C1s in patients with cold agglutinin disease: lessons learned from a named patient program. Blood Adv 4:997-1005. https://doi.org/ 10.1182/bloodadvances.2019001321

87. Jäger U, D'Sa S, Schörgenhofer C, Bartko J, Derhaschnig U, Sillaber C, Jilma-Stohlawetz P, Fillitz M, Schenk T, Patou G, Panicker S, Parry GC, Gilbert JC, Jilma B (2019) Inhibition of complement $\mathrm{C} 1 \mathrm{~s}$ improves severe hemolytic anemia in cold agglutinin disease: a first-in-human trial. Blood 133:893-901. https://doi.org/10.1182/blood-2018-06-856930 
88. Macedo ACL, Isaac L (2016) Systemic lupus erythematosus and deficiencies of early components of the complement classical pathway. Front Immunol 7:1-7. https://doi.org/10.3389/fimmu. 2016.00055

89. Koles K, van Berkel PHC, Pieper FR, Nuijens JH, Mannesse ML, Vliegenthart JF, Kamerling JP (2004) N- and O-glycans of recombinant human $\mathrm{C} 1$ inhibitor expressed in the milk of transgenic rabbits. Glycobiology 14:51-64. https://doi.org/10.1093/glycob/ cwh010

90. Wouters D, Wagenaar-Bos I, Van Ham M, Zeerleder S (2008) C1 inhibitor: just a serine protease inhibitor? New and old considerations on therapeutic applications of $\mathrm{C} 1$ inhibitor. Expert Opin Biol Ther 8:1225-1240. https://doi.org/10.1517/14712598.8.8. 1225

91. Caliezi C, Wuillemin WA, Zeerleder S, Redondo M, Eisele B, Hack CE (2000) C1-esterase inhibitor: an anti-inflammatory agent and its potential use in the treatment of diseases other than hereditary angioedema. Pharmacol Rev 52:91-112

92. Lafayette RA, Rovin BH, Reich HN, Tumlin JA, Floege J, Barratt J (2020) Safety, tolerability and efficacy of narsoplimab, a novel MASP-2 inhibitor for the treatment of IgA nephropathy. Kidney Int Reports 5:2032-2041. https://doi.org/10.1016/j.ekir.2020.08. 003

93. Rambaldi A, Gritti G, Micò MC, Frigeni M, Borleri G, Salvi A, Landi F, Pavoni C, Sonzogni A, Gianatti A, Binda F, Fagiuoli S, di Marco F, Lorini L, Remuzzi G, Whitaker S, Demopulos G (2020) Endothelial injury and thrombotic microangiopathy in COVID-19: treatment with the lectin-pathway inhibitor narsoplimab. Immunobiology 225:152001. https://doi.org/10. 1016/j.imbio.2020.152001

94. Elhadad S, Chapin J, Copertino D, van Besien K, Ahamed J, Laurence J (2021) MASP2 levels are elevated in thrombotic microangiopathies: association with microvascular endothelial cell injury and suppression by anti-MASP2 antibody narsoplimab. Clin Exp Immunol 203:96-104. https://doi.org/10.1111/cei. 13497

95. Shi J, Rose EL, Singh A, Hussain S, Stagliano NE, Parry GC, Panicker S (2014) TNT003, an inhibitor of the serine protease $\mathrm{C} 1 \mathrm{~s}$, prevents complement activation induced by cold agglutinins. Blood 123:4015-4022. https://doi.org/10.1182/blood-2014-02556027

96. Lansita JA, Mease KM, Qiu H, Yednock T, Sankaranarayanan S, Kramer S (2017) Nonclinical development of ANX005: a humanized anti-C1q antibody for treatment of autoimmune and neurodegenerative diseases. Int J Toxicol 36:449-462. https://doi.org/10. $1177 / 1091581817740873$

97. Van de Walle I, Silence K, Budding K et al (2020) ARGX-117, a therapeutic complement inhibiting antibody targeting $\mathrm{C} 2$. J Allergy Clin Immunol 147:1420-1429.e7. https://doi.org/10. 1016/j.jaci.2020.08.028

98. Boross P, Yildiz C, Simons PJ et al (2016) A monoclonal antibody against complement $\mathrm{C} 2$, as a novel complement inhibitor. In: Altant Conference 2016: Innate Host Defence. Utrecht, Netherlands

99. de Castro C, Grossi F, Weitz IC et al (2020) C3 inhibition with pegcetacoplan in subjects with paroxysmal nocturnal hemoglobinuria treated with eculizumab. Am J Hematol 95:1334-1343. https://doi.org/10.1002/ajh.25960

100. Song $\mathrm{C}, \mathrm{Xu} \mathrm{Z}$, Miao J, Xu J, Wu X, Zhang F, Lin H, Li Z, Kaminski HJ (2012) Protective effect of scFv-DAF fusion protein on the complement attack to acetylcholine receptor: a possible option for treatment of myasthenia gravis. Muscle Nerve 45: 668-675. https://doi.org/10.1002/mus.23247

101. Kusner LL, Satija N, Cheng G, Kaminski HJ (2014) Targeting therapy to the neuromuscular junction: proof of concept. Muscle Nerve 49:749-756. https://doi.org/10.1002/mus.24057
102. Fridkis-Hareli M, Storek M, Mazsaroff I, Risitano AM, Lundberg AS, Horvath CJ, Holers VM (2011) Design and development of TT30, a novel C3d-targeted C3/C5 convertase inhibitor for treatment of human complement alternative pathway-mediated diseases. Blood 118:4705-4713. https://doi.org/10.1182/blood2011-06-359646

103. Risitano AM, Notaro R, Pascariello C (2012) The complement receptor 2 /factor $\mathrm{H}$ fusion protein TT30 protects paroxysmal nocturnal hemoglobinuria erythrocytes from complement-mediated hemolysis and C3 fragment (Blood (2012) 119, 26 (63076316)). Blood 120:4903. https://doi.org/10.1182/blood-2012-10464552

104. Mulligan MS, Yeh CG, Rudolph AR, Ward PA (1992) Protective effects of soluble CR1 in complement- and neutrophil-mediated tissue injury. J Immunol 148:1479-1485

105. Schmid RA, Hillinger S, Hamacher J, Stammberger U (2001) TP20 is superior to TP10 in reducing ischemia/reperfusion injury in rat lung grafts. Transplant Proc 33:948-949. https://doi.org/10. 1016/S0041-1345(00)02279-X

106. Smith GP, Smith RAG (2001) Membrane-targeted complement inhibitors. Mol Immunol 38:249-255. https://doi.org/10.1016/ S0161-5890(01)00047-5

107. Li JS, Jaggers J, Anderson PAW (2006) The use of TP10, soluble complement receptor 1, in cardiopulmonary bypass. Expert Rev Cardiovasc Ther 4:649-654. https://doi.org/10.1586/14779072.4. 5.649

108. Yang Y, Denton H, Davies OR, Smith-Jackson K, Kerr H, Herbert AP, Barlow PN, Pickering MC, Marchbank KJ (2018) An engineered complement factor $\mathrm{H}$ construct for treatment of $\mathrm{C} 3$ glomerulopathy. J Am Soc Nephrol 29:1649-1661. https://doi. org/10.1681/ASN.2017091006

109. Souza DG, Esser D, Bradford R, Vieira AT, Teixeira MM (2005) APT070 (Mirococept), a membrane-localised complement inhibitor, inhibits inflammatory responses that follow intestinal ischaemia and reperfusion injury. Br J Pharmacol 145:1027-1034. https://doi.org/10.1038/sj.bjp.0706286

110. Patel H, Smith RAG, Sacks SH, Zhou W (2006) Therapeutic strategy with a membrane-localizing complement regulator to increase the number of usable donor organs after prolonged cold storage. J Am Soc Nephrol 17:1102-1111. https://doi.org/10. 1681/ASN.2005101116

111. Kassimatis T, Qasem A, Douiri A, Ryan EG, Rebollo-Mesa I, Nichols LL, Greenlaw R, Olsburgh J, Smith RA, Sacks SH, Drage M (2017) A double-blind randomised controlled investigation into the efficacy of Mirococept (APT070) for preventing ischaemia reperfusion injury in the kidney allograft (EMPIRIKAL): study protocol for a randomised controlled trial. Trials 18:1-11. https://doi.org/10.1186/s13063-017-1972-x

112. Wang X, Van Lookeren CM, Katschke KJ et al (2018) Prevention of fatal C3 glomerulopathy by recombinant complement receptor of the Ig superfamily. J Am Soc Nephrol 29:2053-2059. https:// doi.org/10.1681/ASN.2018030270

113. Chen M, Muckersie E, Luo C, Forrester JV, Xu H (2010) Inhibition of the alternative pathway of complement activation reduces inflammation in experimental autoimmune uveoretinitis. Eur J Immunol 40:2870-2881. https://doi.org/10.1002/eji. 201040323

114. Chow V, Pan J, Chien D, Mytych DT, Hanes V (2020) A randomized, double-blind, single-dose, three-arm, parallel group study to determine pharmacokinetic similarity of ABP 959 and eculizumab (Soliris ${ }^{\circledR}$ ) in healthy male subjects. Eur J Haematol 105:66-74. https://doi.org/10.1111/ejh.13411

115. Hill A, Rother RP, Arnold L, Kelly R, Cullen MJ, Richards SJ, Hillmen P (2010) Eculizumab prevents intravascular hemolysis in patients with paroxysmal nocturnal hemoglobinuria and unmasks low-level extravascular hemolysis occurring through $\mathrm{C} 3$ 
opsonization. Haematologica 95:567-573. https://doi.org/10. 3324/haematol.2009.007229

116. Röth A, Nishimura JI, Nagy Z, Gaàl-Weisinger J, Panse J, Yoon SS, Egyed M, Ichikawa S, Ito Y, Kim JS, Ninomiya H, Schrezenmeier H, Sica S, Usuki K, Sicre de Fontbrune F, Soret J, Sostelly A, Higginson J, Dieckmann A, Gentile B, AnzuresCabrera J, Shinomiya K, Jordan G, Biedzka-Sarek M, Klughammer B, Jahreis A, Bucher C, Peffault de Latour R (2020) The complement C5 inhibitor crovalimab in paroxysmal nocturnal hemoglobinuria. Blood 135:912-920. https://doi.org/ 10.1182/BLOOD.2019003399

117. Latuszek A, Liu Y, Olsen O, Foster R, Cao M, Lovric I, Yuan M, Liu N, Chen H, Zhang Q, Xiao H, Springer C, Ehrlich G, Kamat V, Rafique A, Hu Y, Krueger P, Huang T, Poueymirou W, Babb R, Rosconi MP, Retter MW, Chen G, Morton L, Zambrowicz B, Cao J, Romano C, Olson WC (2020) Inhibition of complement pathway activation with pozelimab, a fully human antibody to complement component C5. PLoS One 15:1-23. https://doi.org/ 10.1371/journal.pone.0231892

118. Gorman DM, Lee J, Payne CD, Woodruff TM, Clark RJ (2021) Chemical synthesis and characterisation of the complement $\mathrm{C} 5$ inhibitory peptide zilucoplan. Amino Acids 53:5-9. https://doi. org/10.1007/s00726-020-02921-5

119. Badri P, Jiang X, Borodovsky A, Najafian N, Kim J, Clausen VA, Goel V, Habtemariam B, Robbie GJ (2020) Pharmacokinetic and pharmacodynamic properties of cemdisiran, an RNAi therapeutic targeting complement component 5 , in healthy subjects and patients with paroxysmal nocturnal hemoglobinuria. Clin Pharmacokinet 60:365-378. https://doi.org/10.1007/s40262-02000940-9

120. Vlaar APJ, de Bruin S, Busch M, Timmermans SAMEG, van Zeggeren IE, Koning R, ter Horst L, Bulle EB, van Baarle FEHP, van de Poll MCG, Kemper EM, van der Horst ICC, Schultz MJ, Horn J, Paulus F, Bos LD, Wiersinga WJ, Witzenrath M, Rueckinger S, Pilz K, Brouwer MC, Guo RF, Heunks L, van Paassen P, Riedemann NC, van de Beek D (2020) Anti-C5a antibody IFX-1 (vilobelimab) treatment versus best supportive care for patients with severe COVID-19 (PANAMO): an exploratory, open-label, phase 2 randomised controlled trial. Lancet Rheumatol 2:e764-e773

121. Merkel PA, Jayne DR, Wang C, Hillson J, Bekker P (2020) Evaluation of the safety and efficacy of avacopan, a C5a receptor inhibitor, in patients with antineutrophil cytoplasmic antibodyassociated vasculitis treated concomitantly with rituximab or cyclophosphamide/azathioprine: protocol for a randomized, doubl. JMIR Res Protoc 9:e16664. https://doi.org/10.2196/16664

122. Jayne DRW, Bruchfeld AN, Harper L, Schaier M, Venning MC, Hamilton P, Burst V, Grundmann F, Jadoul M, Szombati I, Tesar̆ V, Segelmark M, Potarca A, Schall TJ, Bekker P, CLEAR Study Group (2017) Randomized trial of C5a receptor inhibitor avacopan in ANCA-associated vasculitis. J Am Soc Nephrol 28: 2756-2767. https://doi.org/10.1681/ASN.2016111179

123. Lee M, Narayanan S, McGeer EG, McGeer PL (2014) Aurin tricarboxylic acid protects against red blood cell hemolysis in patients with paroxysmal nocturnal hemoglobinemia. PLoS One 9:1-7. https://doi.org/10.1371/journal.pone.0087316

124. Lee M, Guo JP, McGeer EG, McGeer PL (2013) Aurin tricarboxylic acid self-protects by inhibiting aberrant complement activation at the $\mathrm{C} 3$ convertase and $\mathrm{C} 9$ binding stages. Neurobiol Aging 34:1451-1461. https://doi.org/10.1016/j.neurobiolaging.2012.10. 023

125. Leinhase I, Rozanski M, Harhausen D, Thurman JM, Schmidt OI, Hossini AM, Taha ME, Rittirsch D, Ward PA, Holers VM, Ertel W, Stahel PF (2007) Inhibition of the alternative complement activation pathway in traumatic brain injury by a monoclonal anti-factor B antibody: a randomized placebo-controlled study in mice. J Neuroinflammation 4:1-12. https://doi.org/10.1186/17422094-4-13

126. Mainolfi N, Ehara T, Karki RG, Anderson K, Mac Sweeney A, Liao SM, Argikar UA, Jendza K, Zhang C, Powers J, Klosowski DW, Crowley M, Kawanami T, Ding J, April M, Forster C, Serrano-Wu M, Capparelli M, Ramqaj R, Solovay C, Cumin F, Smith TM, Ferrara L, Lee W, Long D, Prentiss M, de Erkenez A, Yang L, Liu F, Sellner H, Sirockin F, Valeur E, Erbel P, Ostermeier D, Ramage P, Gerhartz B, Schubart A, Flohr S, Gradoux N, Feifel R, Vogg B, Wiesmann C, Maibaum J, Eder J, Sedrani R, Harrison RA, Mogi M, Jaffee BD, Adams CM (2020) Discovery of 4-((2 S,4 S)-4-Ethoxy-1-((5-methoxy-7-methyl-1 Hindol-4-yl)methyl)piperidin-2-yl)benzoic acid (LNP023), a factor $\mathrm{B}$ inhibitor specifically designed to be applicable to treating a diverse array of complement mediated diseases. J Med Chem 63:5697-5722. https://doi.org/10.1021/acs.jmedchem.9b01870

127. Holz FG, Sadda SR, Busbee B, Chew EY, Mitchell P, Tufail A, Brittain C, Ferrara D, Gray S, Honigberg L, Martin J, Tong B, Ehrlich JS, Bressler NM, for the Chroma and Spectri Study Investigators (2018) Efficacy and safety of lampalizumab for geographic atrophy due to age-related macular degeneration: chroma and spectri phase 3 randomized clinical trials. JAMA Ophthalmol 136:666-677. https://doi.org/10.1001/jamaophthalmol.2018.1544

128. Risitano AM, Kulasekararaj AG, Lee JW, Maciejewski JP, Notaro R, Brodsky R, Huang M, Geffner M, Browett P (2020) Danicopan: an oral complement factor D inhibitor for paroxysmal nocturnal hemoglobinuria. Haematologica Online ahe:0. https:// doi.org/10.3324/haematol.2020.261826

129. Pouw RB, Brouwer MC, de Gast M, van Beek AE, van den Heuvel LP, Schmidt CQ, van der Ende A, Sánchez-Corral P, Kuijpers TW, Wouters D (2019) Potentiation of complement regulator factor $\mathrm{H}$ protects human endothelial cells from complement attack in aHUS sera. Blood Adv 3:621-632. https://doi.org/10. 1182/bloodadvances.2018025692

130. Dekkers G, Brouwer M, Jeremiasse J et al (2020) Unravelling the effect of a potentiating anti-Factor $\mathrm{H}$ antibody on atypical hemolytic uremic syndrome associated factor $\mathrm{H}$ variants. J Immunol 205:1-9

131. Harder MJ, Anliker M, Höchsmann B, Simmet T, Huber-Lang M, Schrezenmeier H, Ricklin D, Lambris JD, Barlow PN, Schmidt CQ (2016) Comparative analysis of novel complement-targeted inhibitors, MiniFH, and the natural regulators factor $\mathrm{H}$ and factor $\mathrm{H}$-like protein 1 reveal functional determinants of complement regulation. J Immunol 196:866-876. https://doi.org/10.4049/ jimmunol.1501919

132. Schmidt CQ, Bai H, Lin Z, Risitano AM, Barlow PN, Ricklin D, Lambris JD (2013) Rational engineering of a minimized immune inhibitor with unique triple-targeting properties. J Immunol 190: 5712-5721. https://doi.org/10.4049/jimmunol.1203548

133. Büttner-Mainik A, Parsons J, Jérôme H, Hartmann A, Lamer S, Schaaf A, Schlosser A, Zipfel PF, Reski R, Decker EL (2011) Production of biologically active recombinant human factor $\mathrm{H}$ in Physcomitrella. Plant Biotechnol J 9:373-383. https://doi.org/10. 1111/j.1467-7652.2010.00552.x

134. Michelfelder S, Parsons J, Bohlender LL, Hoernstein SNW, Niederkrüger H, Busch A, Krieghoff N, Koch J, Fode B, Schaaf A, Frischmuth T, Pohl M, Zipfel PF, Reski R, Decker EL, Häffner K (2017) Moss-produced, glycosylation-optimized human factor $\mathrm{H}$ for therapeutic application in complement disorders. J Am Soc Nephrol 28:1462-1474. https://doi.org/10.1681/ASN. 2015070745

135. De Boer ECW, Van Mourik AG, Jongerius I (2020) Therapeutic lessons to be learned from the role of complement regulators as double-edged sword in health and disease. Front Immunol 11:121. https://doi.org/10.3389/fimmu.2020.578069 
136. Mastellos DC, Yancopoulou D, Kokkinos P, Huber-Lang M, Hajishengallis G, Biglarnia AR, Lupu F, Nilsson B, Risitano AM, Ricklin D, Lambris JD (2015) Compstatin: a C3-targeted complement inhibitor reaching its prime for bedside intervention. Eur J Clin Investig 45:423-440. https://doi.org/10.1111/eci.12419

137. Sahu A, Kay BK, Lambris JD (1996) Inhibition of human complement by a C3-binding peptide isolated from a phage-displayed random peptide library. J Immunol 157:884-891

138. Mastellos DC, Ricklin D, Yancopoulou D, Risitano A, Lambris JD (2014) Complement in paroxysmal nocturnal hemoglobinuria: exploiting our current knowledge to improve the treatment landscape. Expert Rev Hematol 7:583-598. https://doi.org/10.1586/ 17474086.2014.953926

139. Baas I, Delvasto-Nuñez L, Ligthart, Peter Brouwer C, et al (2020) Complement $\mathrm{C} 3$ inhibition by compstatin $\mathrm{Cp} 40$ prevents intraand extravascular hemolysis of red blood cells. Haemotologica 105:471-473. https://doi.org/10.1097/GME.0000000000000638

140. Risitano AM, Ricklin D, Huang Y, Reis ES, Chen H, Ricci P, Lin Z, Pascariello C, Raia M, Sica M, del Vecchio L, Pane F, Lupu F, Notaro R, Resuello RRG, DeAngelis RA, Lambris JD (2014) Peptide inhibitors of $\mathrm{C} 3$ activation as a novel strategy of complement inhibition for the treatment of paroxysmal nocturnal hemoglobinuria. Blood 123:2094-2101. https://doi.org/10.1182/blood2013-11-536573

141. Reis S, DA EF, Isaac L (2006) Clinical aspects and molecular basis of primary deficiencies of complement component $\mathrm{C} 3$ and its regulatory proteins factor I and factor $\mathrm{H}$. Scand J Immunol 63: 155-168. https://doi.org/10.1111/j.1365-3083.2006.01729.x

142. Zeerleder S, Levi M (2016) Hereditary and acquired C1-inhibitordependent angioedema: from pathophysiology to treatment. Ann Med 48:256-267. https://doi.org/10.3109/07853890.2016. 1162909

143. Mastellos DC, Reis ES, Yancopoulo D et al (2017) Expanding complement therapeutics for the treatment of paroxysmal nocturnal hemoglobinuria. Physiol Behav 176:139-148. https://doi.org/ 10.1016/j.physbeh.2017.03.040

144. Kassa E, Ciulla TA, Hussain RM, Dugel PU (2019) Complement inhibition as a therapeutic strategy in retinal disorders. Expert Opin Biol Ther 19:335-342. https://doi.org/10.1080/14712598. 2019.1575358

145. Kim HK, Kim JE, Wi HC, Lee SW, Kim JY, Kang HJ, Kim YT (2008) Aurintricarboxylic acid inhibits endothelial activation, complement activation, and von Willebrand factor secretion in vitro and attenuates hyperacute rejection in an ex vivo model of pig-to-human pulmonary xenotransplantation. Xenotransplantation 15:246-256. https://doi.org/10.1111/j.13993089.2008.00481.x

Publisher's note Springer Nature remains neutral with regard to jurisdictional claims in published maps and institutional affiliations. 